\title{
Sentinel Gap Basait Reacted in a Temperature Gradient
}

\author{
R. W. Charles \\ G. K. Bayhurst
}

\section{DISCLAIMER}

This report was prepared as an account of work sponsored by an agency of the United States Government. Neither the United States Government nor any afency thereor, nor any of their employees, makes any warranty, express or implied, or assumes any lesal liability or reapoenibility for the accuracy, completeness, or usefulness of any information, apparsius, product, or process disclosed, or represents that its use would not infringe privately owned rights. Reference herein to any specific commercial product, process, or service by trade name, trademark, manufacturet, or otherwise does not pecessarily constitute or imply its endorsement, recommendation, or favoring by the United States Government or any usency thereof. The viem and opinions of authors expressed herein do not necessarily state or reflect thowe of the United States Government or any agency thereof.

\section{MASTER}


SENTINEL GAP BASALT REACTED IN A TEMPERATURE GRADIENT

by

R. W. Charles and G. K. Bayhurst

\begin{abstract}
Six basalt prisms were reacted in a coutrolled temperature gradient hydrothermal circulation system for two months. The prisus were centered at 72, 119, $161,209,270$, and $310^{\circ} \mathrm{C}$. Total pressure was $1 / 3 \mathrm{kbar}$. All prisus showed large weight loss: $5.5 \%$ to $14.9 \%$. The matrix micropegmatite and natural nontronitic alteration reacted readily to clays at all temperatures. The first four prises were coated with a calcium smectite, and the last two prises were covered with discrete patches of potassium-rich phengite and alkali feldspar. The results indicated that clays may act as adsorbers of various ions.
\end{abstract}

\title{
I. INTRODUCTION
}

Basalt is being considered as a host rock for a radioactive waste repository. ${ }^{1-4}$ One of the basalts under consideration is the Grande Ronde basalt of the Yakina Subgroup of the Columbia River Basin Group. Chenical reactions involving such basalt with groundwater are of interest to those working with any repository involving basalt. In the experiments presented here, a basalt sample from one of the flows of the Sentinel Bluff flows in a controlled terperature gradient circulation system under constant pressure in water that wes initially distilled for a period of two wonths. The purpose of these experiments is to define some of the reaction relations between the fluid and basalt as well as the mass transport. 


\section{II . THE EXPERIMENT}

Figure 1 exhibits the controlled temperature gradient system. Flow is clockwise. Details of the system's operation are given in Refs. 5 and 6 . Six polished prisms of basalt $(2.5 \mathrm{~cm} \times 0.6 \mathrm{~cm} \times 0.6 \mathrm{~cm})$ were placed in a vessel in which a temperature gradient could be imposed at temperatures of 72,119 , $169,209,270$, and $310^{\circ} \mathrm{C}$ with fluid flow from cool to hot. Total pressure was $1 / 3 \mathrm{kbar}$. All of the prisms were removed after 60 days of reaction time.

After $1,2,6,14$, and 30 days, the solution was sampled at the two points labeled with constant pressure and temperature samplers. The samplers are explained in Refs. $\mathbf{i}-6$. (A final sample, taken from the cooled fluid after 60 days, showed fractionation and is not included herein.) The fluid reached a steady state after 6 to 14 days. Solutions were analysed by plasma emission spectrometry. Rock prisms were examined using a scanning electron microscope (SEM) with a nondispersive detector, an electron microprobe, and an optical microscope. Thin sections were prepared for each rock prism, so interiors as well as surfaces could be examined.

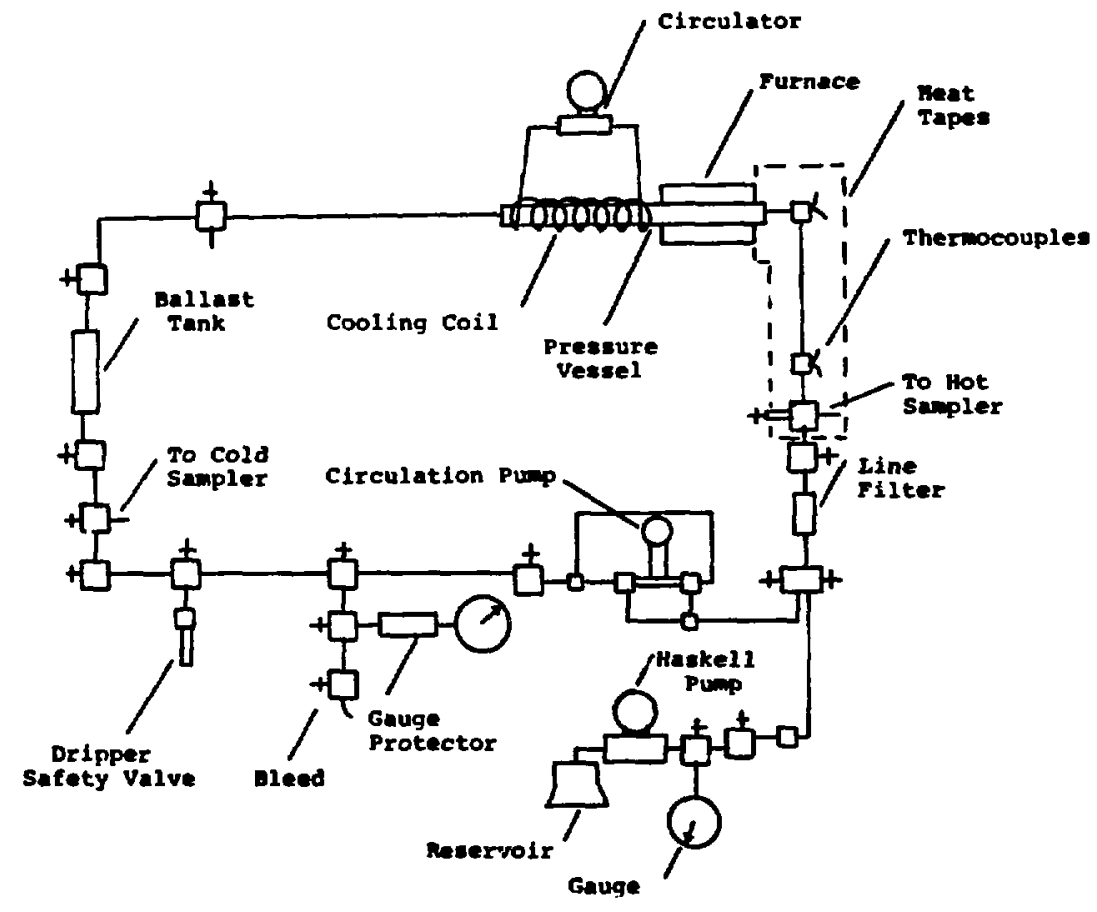

Fig. 1. Controlled temperature gradient circulation system. 
The aphanitic basalt shows a subophitic texture with intersertial nontronite and micr graphic alkali feldspar plus quar1:z. The principle phases are augite, pigeonite, sodic labradorite, titaniferous magnetite, nontronite, and matrix. The matrix is a micropegmatite with a rhyolite norm. Normalized to Or-Ab-Q, the groundmass, while showing wide scatter, plots near the minimum melting point of granite (see Fig. 2). The normative concentration of the basalt is quartz-hypersthene. See Table I for details of phase composition, whole rock analyses, and norm.

\section{I . RESULTS}

\section{A. Weight Loss}

The basalt prisms showed rather high weight losses (Fig. 3 and Table II). The prism at $72^{\circ} \mathrm{C}$ showed a loss of $5.5 \%$ in two months of reaction time, and the prism at $310^{\circ} \mathrm{C}$ showed a loss of $14.9 \%$. Included for comparison (in Fig. 3) is an experiment that was done under identical run conditions, except the rock was a granodiorite 9519, from the Fenton Hill HDR reservoir. At no time does the basalt show actual weight gains as does the granodiorite (at 72 and $119^{\circ} \mathrm{C}$ ).

\section{B. Solution Analyses}

Solutions in contact with basalt seemed to reach a steady state at about 6 days (hot sample) and continue at this level for the remainder of the experiment (Table III, Fig. 4). Hot sample was extracted at $310^{\circ} \mathrm{C}$; cold sample was extracted at room temperature. Initial maximums were observed (cold solution) for $\mathrm{SiO}_{2}$, potassiun, sodiun, and possibly iron and calcium.

C. Morphological Changes

Scanning electron photomosaics of prisus in various stages of the reaction process are shown in the appendix (Figs. A-1 through A-8). Figure A-1 shows an unreacted rock prism. The darkest material is plagioclase and nicropegmatite, and the gray material is pyroxene. Opaques are lightest. The only surface relief is some plucking caused by polishing.

Overgrowth morphology occurs in two types.

(1) All pervasive clay at $72,119,161$, and $209^{\circ} \mathrm{C}$.

(2) Discrete clay overgrowths plus feldspar at 270 and $310^{\circ} \mathrm{C}$. 


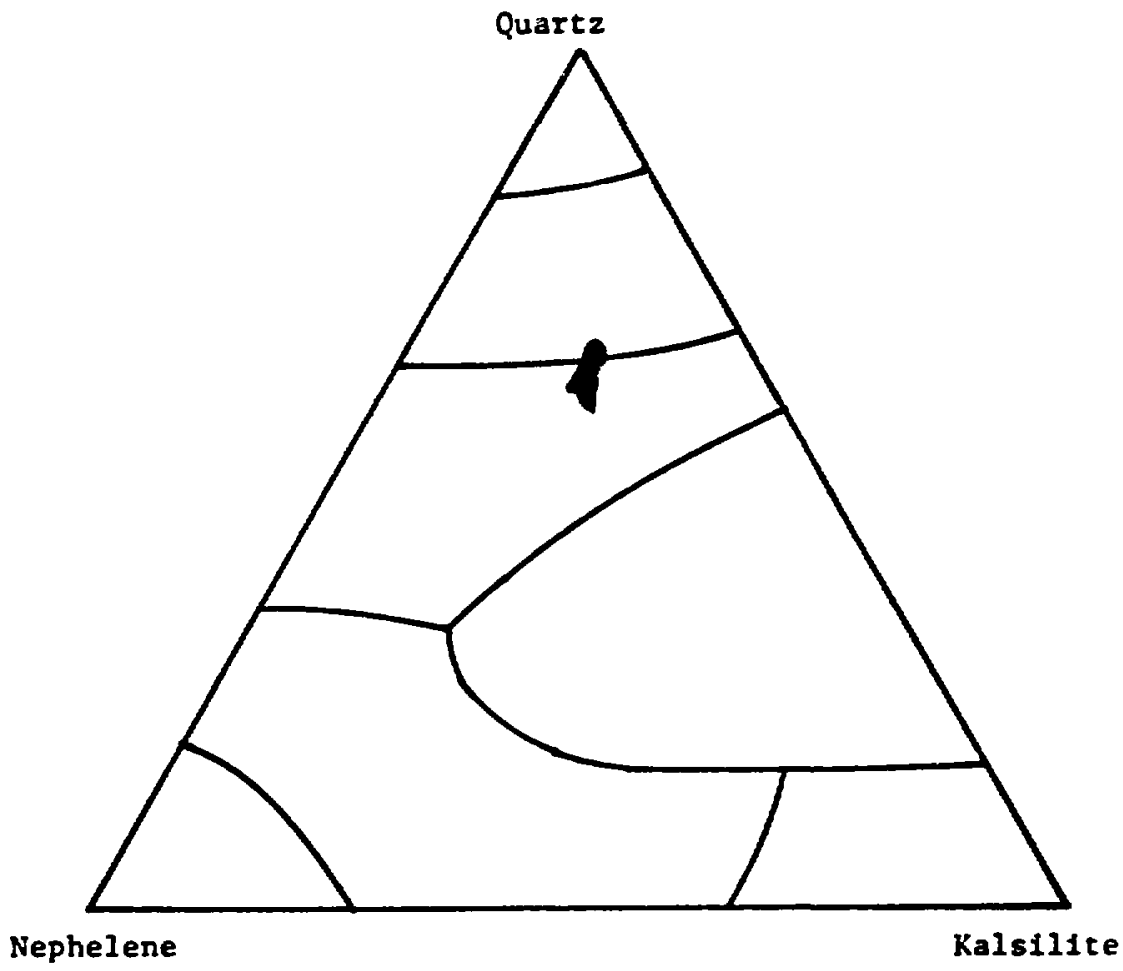

Fig. 2. Quartz-nephelene-kalsilite projection with "keyhole"-shaped plot of basalt matrix compositions near granite minimum melting.

Figure A-2 shows a portion of the rock prism reacted at $72^{\circ} \mathrm{C}$. Much reaction has occurred. "Fracture" openings and voids represent dissolution of micropegmatite. Secondary precipitation consisting of botriodal platey aggregates is shown in Fig. A-3. The platey aggregates cover the rock surface more completely at $119^{\circ} \mathrm{C}$ (Fig. A-4). Cavities are in the matrix. Figure A-5 shows the same overgrowth, in this case at $161^{\circ} \mathrm{C}$. The same overgrowth persists to $209^{\circ} \mathrm{C}$ (Fig. A-6).

Overgrowth morphology changes strikingly at $270^{\circ} \mathrm{C}$ (Fig. A-7). Two phases now cover the basalt surfaces. Clay of a different composition surrounds laths of recrystallized feldspar. Figure A-8 presents a portion of the $310^{\circ} \mathrm{C}$ pris showing similar morphology with possibly slightly better crystallization of the feldspars. Note in particular the euhedral crystals at 6 o'clock and $90^{\prime}$ clock. 
TABLE I

SENTINEL GAP BASALT WHOLE ROCK ANALYSIS, NORM, AND MINERALOGY

\begin{tabular}{|c|c|c|c|c|}
\hline \multicolumn{2}{|c|}{ Wt \% Oxides } & & \multicolumn{2}{|c|}{ Norm $(\%)$} \\
\hline $\mathrm{SiO}_{2}$ & 53.00 & & il & 2.74 \\
\hline $\mathrm{TiO}_{2}$ & 1.93 & & ap & 0.17 \\
\hline $\mathrm{Al}_{2} \mathrm{O}_{3}$ & 14.80 & & or & 7,00 \\
\hline $\mathrm{Fe}_{2} \mathrm{O}_{3}$ & 2.00 & & $\mathbf{a b}$ & 24.81 \\
\hline $\mathrm{FeO}$ & 10.87 & & an & 25.40 \\
\hline $\mathrm{CaO}$ & 8.43 & & $\mathrm{mt}$ & 2.13 \\
\hline $\mathrm{MgO}$ & 4.59 & & di & 13.80 \\
\hline $\mathrm{Na}_{2} \mathrm{O}$ & 2.70 & $\therefore$ & hy & 19.58 \\
\hline $\mathrm{K}_{2} \mathrm{O}$ & 1.15 & & $Q$ & 4.37 \\
\hline MnO & 0.22 & & & \\
\hline $\mathrm{P}_{2} \mathrm{O}_{5}$ & 0.31 & & & \\
\hline
\end{tabular}

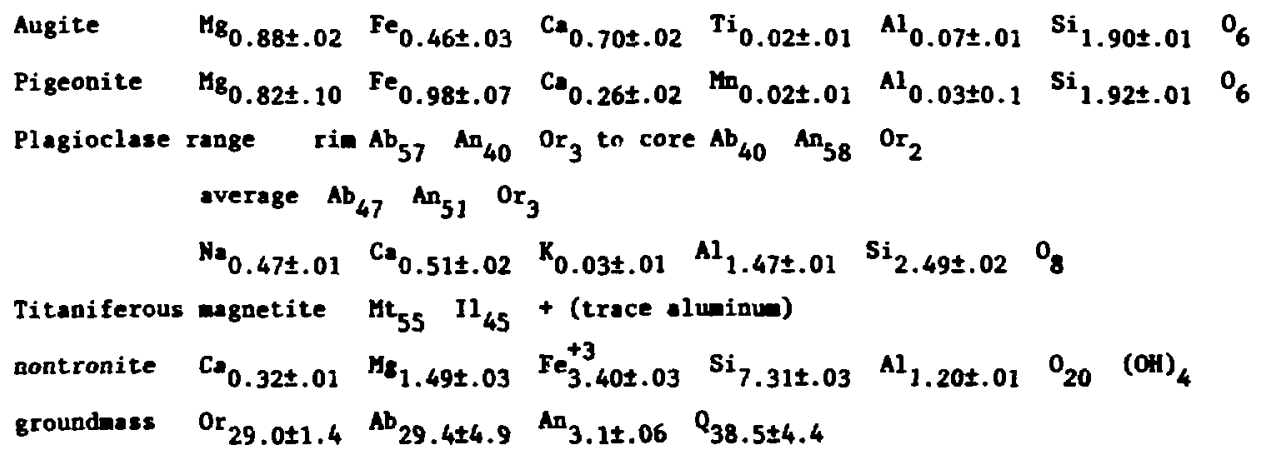




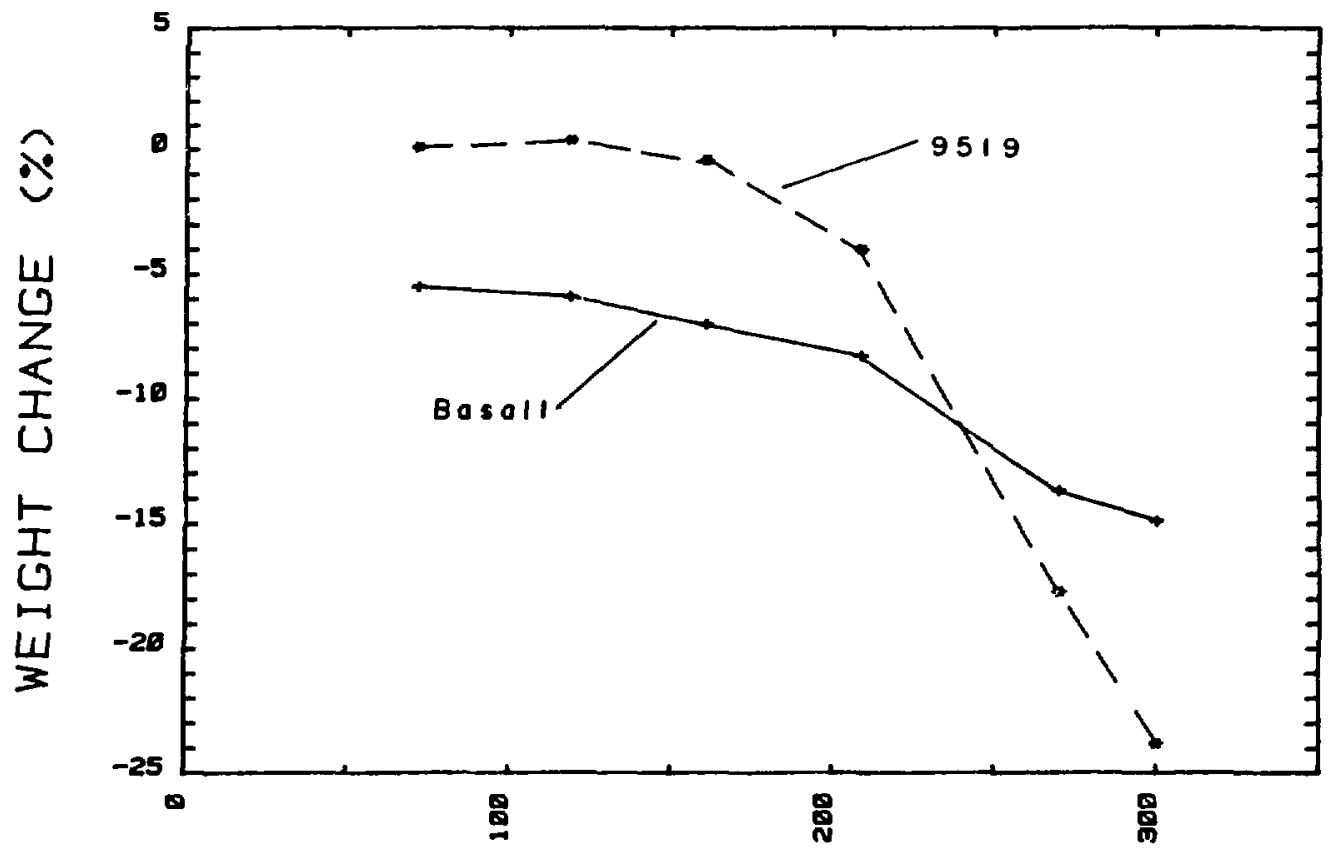

TEMPERATURE (C)

Fig. 3. Weight change of basalt prisms compared to weight change of granodiorite 9519 .

TABLE II

BASALT PRISM WEIGHT LOSS

Weight

\begin{tabular}{cc} 
Prism & $\begin{array}{c}\text { Original } \\
(\mathrm{g})\end{array}$ \\
\cline { 2 - 2 } 1 & 3.0377 \\
2 & 3.0145 \\
3 & 3.0595 \\
4 & 3.0525 \\
5 & $3.6 \% 40$ \\
6 & 3.0172
\end{tabular}

Change
Final
$\frac{(8)}{2.8708}$
2.8373
2.8445
2.7980
2.6438
2.5675

\begin{tabular}{ll}
\multicolumn{2}{c}{ Change } \\
\hline$\frac{(g)}{-0.1669}$ & $\frac{(\%)}{-5.5}$ \\
-0.1722 & -5.9 \\
-0.2150 & -7.0 \\
-0.2545 & -8.3 \\
-0.4202 & -13.7 \\
-0.4497 & -14.9
\end{tabular}


TABLE III

ANALYSES OF SOLUTIONS IN CONTACT WITH BASALT ${ }^{a}$

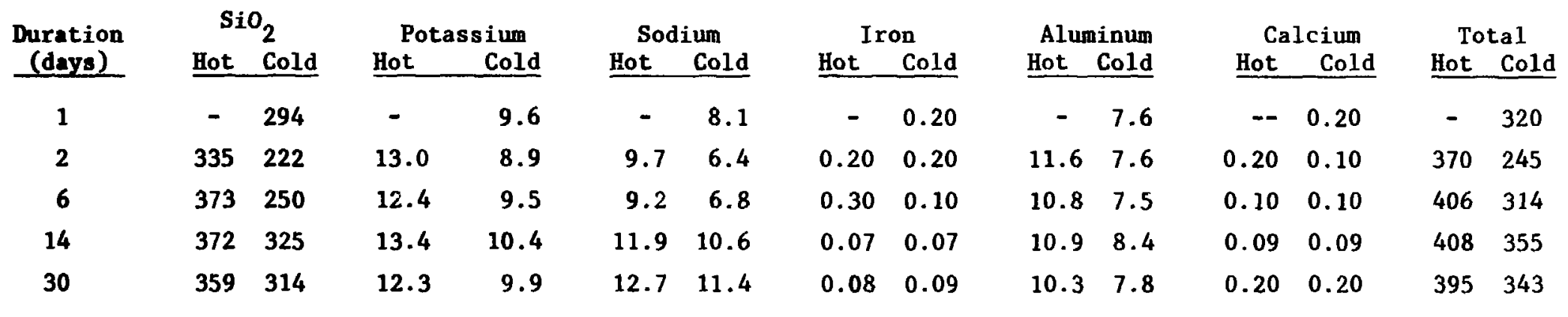

an parts per million. 

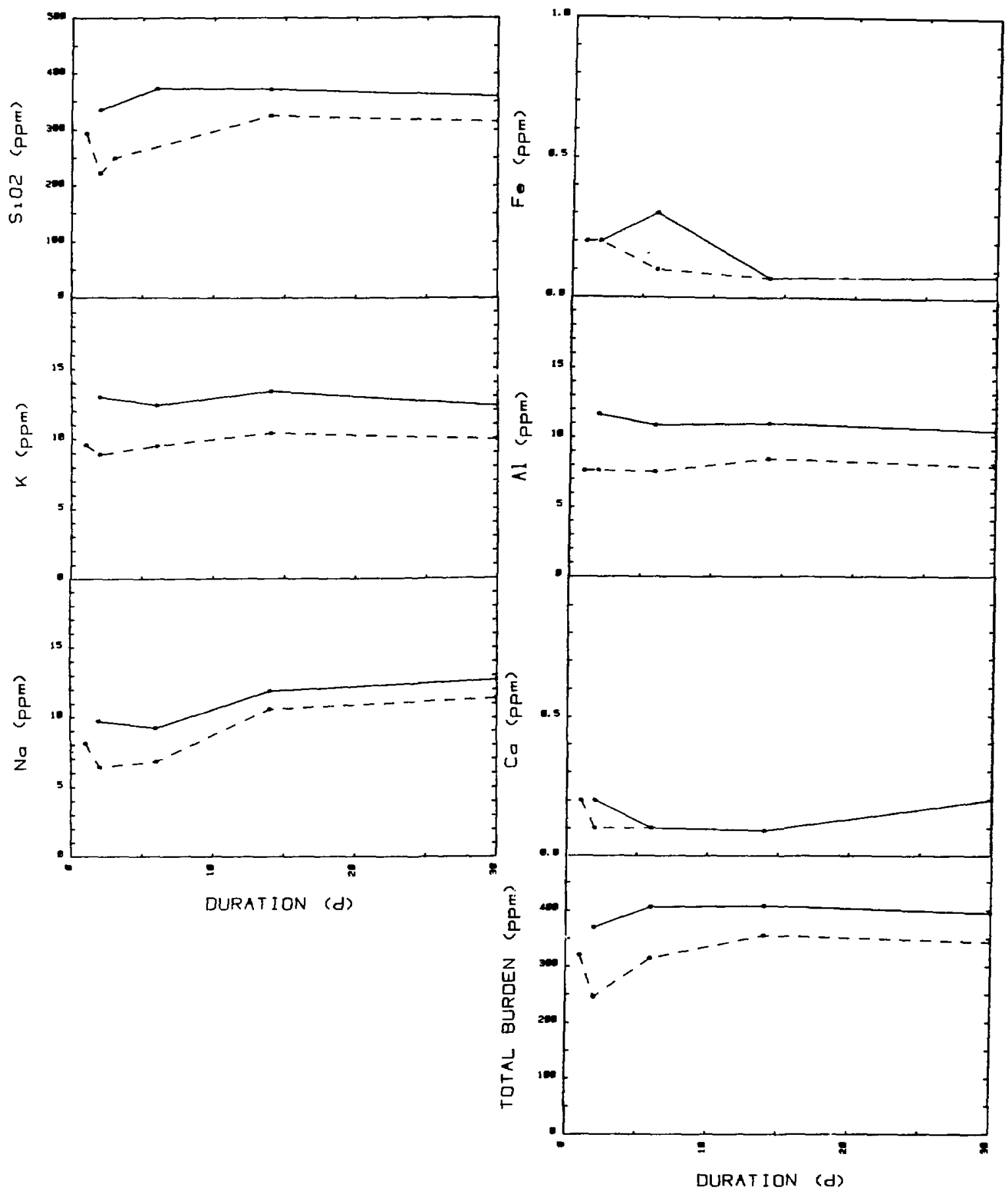

Fig. 4. Solution analyses. 
D. Chemical Changes

Reactivity of the basalt varied from nonexistent to major. Table IV displays the reactivity of some of the primary phases. The analyses are from thin sections prepared from each of the six prisms. Plagioclase, augite, and pigeonite show little reaction.

Micropegmatite shows the most reactivity. Most important is the lack of free silica from norms calculated for the reacted micropegmatite (Fig. 5a). Normative anorthite shows a more or less steady increase (Fig. 5b), while normative albite steadily decreases (Fig. 5c). Normative Kspar may actually peak at about $270^{\circ} \mathrm{C}$, becoming more reactive at $310^{\circ} \mathrm{C}$ (Fig. $5 \mathrm{~d}$ ). Cumulative norms are shown in Fig. 5e.

Nontronite also displays a gross change in composition from the original. Generally, silicon is leached. The resultant product has a more variable iron content than before and possibly higher magnesium. The Si/Al ratio for original nontronite is compared with reacted material in Fig. 6.

Surface analyses by electron microprobe and SEM yielded particularly poor analyses (Table V) from the standpoint of variability and poor totals. The rough surface and possibly variable composition contributed to this problem. A clay was identified on the $72,119,161$, and $209^{\circ} \mathrm{C}$ prisms with the composition shown. Total magnesium + iron was near constant at about 5.5, and aluminum + silicon was near constant at about 8 , although magnesium, iron, aluminum, and silicon varied about 0.5 atoms over the range of several dozen analyses. Composition and morphology indicate the material to be a smectite with magnetite inclusions. The Si/Al ratio is similar to the interior reacted nontronite mentioned above (Fig. 7).

A different clay, potassium bearing with a different Si/Al ratio than the previous clay, appears on the 270 and $310^{\circ} \mathrm{C}$ prisms. Also appearing is a phase with prismatic habit with alkali feldspar composition. Sodium and potassiun contents for this second phase are variable, and $\mathrm{Al} / \mathrm{Si}$ was almost $1 / 3$.

IV. DISCUSSION

A. General

All of the primary (original) rock minerals reacted to some extent. Augite, pigeonite, and plagioclase showed clear surface recrystallization to clay. Analyses on the interior of each prism showed these phases to be resistant to 
TABLE IV

SUMMARY OF PHASE COMPOSITIONS:

ANALYSES OF THIN-SECTIONED PRISMS (ATOMIC FORMULAS)

$$
\text { Plagioclase ( } 8 \text { ox })
$$

\begin{tabular}{|c|c|c|c|c|c|c|}
\hline $\begin{array}{c}\mathrm{T} \\
\left({ }^{\circ} \mathrm{C}\right) \\
\end{array}$ & $\mathrm{Na}$ & $\mathrm{Ca}$ & $\mathbf{K}$ & $\mathrm{Al}$ & $\mathrm{Si}$ & $\mathrm{Fe}$ \\
\hline 72 & $0.49 \pm .03$ & $0.53 \pm .04$ & $0.03 \pm .01$ & $1.46 \pm .03$ & $2.49 \pm .04$ & $0.03 \pm .01$ \\
\hline 119 & $0.44 \pm .04$ & $0.51 \pm .06$ & $0.03 \pm .01$ & $1.44 \pm .07$ & $2.51 \pm 0.7$ & $0.03 \pm .01$ \\
\hline 161 & $0.45 \pm .03$ & $0.54 \pm .03$ & $0.02 \pm .01$ & $1.48 \pm .03$ & $2.49 \pm .03$ & $0.03 \pm .01$ \\
\hline 209 & $0.43 \pm .01$ & $0.56 \pm .01$ & $0.03 \pm .01$ & $1.50 \pm .01$ & $2.45 \pm .01$ & $0.03 \pm .01$ \\
\hline 270 & $0.43 \pm .01$ & $0.56 \pm .01$ & $0.02 \pm .01$ & $1.47 \pm .01$ & $2.47 \pm .02$ & $0.04 \pm .01$ \\
\hline 310 & $0.43 \pm .03$ & $0.57 \pm .01$ & $0.01 \pm .01$ & $1.50 \pm .01$ & $2.46 \pm .01$ & $0.04 \pm .01$ \\
\hline
\end{tabular}

$$
\text { Augite (6 ox) }
$$

\begin{tabular}{|c|c|c|c|c|c|c|c|c|}
\hline$\left({ }^{\circ} \mathrm{C}\right)$ & $\mathrm{Na}$ & $\mathrm{Mg}$ & Al & $\mathrm{Si}$ & Mn & $\mathrm{Fe}$ & $\mathrm{Ca}$ & $\mathrm{Ti}$ \\
\hline 72 & $0.02 \pm .01$ & $0.81 \pm .02$ & $0.07 \pm .01$ & $1.92 \pm .01$ & $0.01 \pm .01$ & $0.51 \pm .02$ & $0.67 \pm .02$ & $0.02 \pm .01$ \\
\hline 19 & -- & 0.84 & 0.08 & 1.90 & 0.01 & 0.48 & 0.70 & 0.02 \\
\hline 61 & $0.02 \pm .01$ & $0.89 \pm .03$ & $0.07 \pm .01$ & $1.90 \pm .01$ & $0.01 \pm .01$ & $0.42 \pm .03$ & $0.70 \pm .01$ & $0.02 \pm .01$ \\
\hline 09 & -- & 0.79 & 0.07 & 1.92 & 007 & 0.60 & 0.60 & 0.02 \\
\hline 270 & $0.02 \pm .01$ & $0.82 \pm .03$ & $0.08 \pm .01$ & $1.91 \pm .01$ & $0.01 \pm .01$ & $0.53 \pm .02$ & $0.65 \pm .04$ & $0.02 \pm .01$ \\
\hline 310 & $0.02 \pm .01$ & $0.86 \pm .02$ & $0.07 \pm .01$ & $1.91 \pm .01$ & -- & $0.48 \pm .02$ & $0.69 \pm .01$ & $0.03 \pm .01$ \\
\hline
\end{tabular}

\section{Pigeonite ( 6 ox)}

$\begin{array}{rcccccccc}\begin{array}{c}\mathrm{T} \\ \left({ }^{\circ} \mathrm{C}\right)\end{array} & \frac{\mathrm{Mg}}{72} & \frac{\mathrm{Al}}{0.94} & 0.03 & \frac{\mathrm{Si}}{1.93} & \frac{\mathrm{Mn}}{--} & \frac{\mathrm{Fe}}{0.87} & \frac{\mathrm{Ca}}{0.21} & \frac{\mathrm{Ti}}{-} \\ 119 & 0.80 & 0.03 & 1.94 & 0.02 & 1.00 & 0.23 & \mathrm{C.02} \\ 161 & 0.80 & 0.07 & 1.89 & 0.02 & 0.97 & 0.27 & 0.01 \\ 209 & 0.93 & 0.03 & 1.95 & 0.02 & 0.84 & 0.23 & - \\ 270 & 0.90 & 0.03 & 1.93 & 0.02 & 0.87 & 0.25 & 0.02 \\ 310 & 1.07 & 0.03 & 1.93 & 0.02 & 0.76 & 0.20 & \ldots\end{array}$


TABLE IV (cont)

Matrix: Micropegmatite

$\mathrm{Ab}=$ albite, Or = Kspar, An = anorthite, $\mathrm{Q}=$ quartz

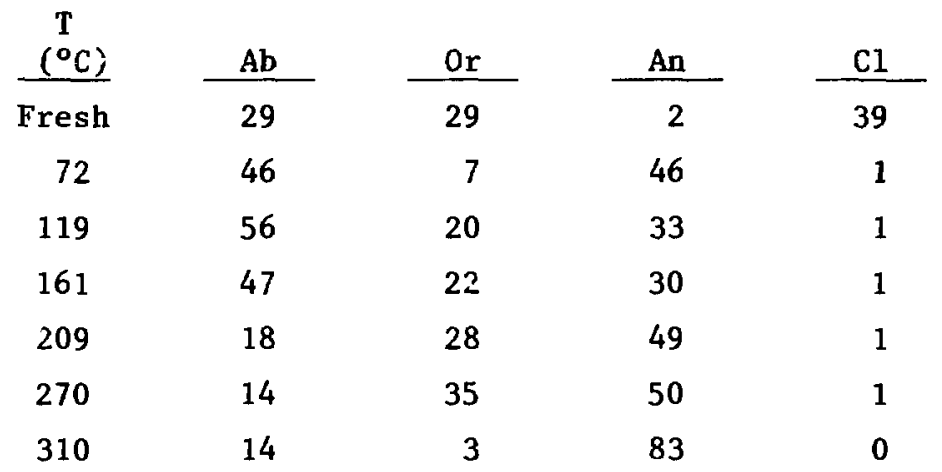

Nontronite $(24,(\mathrm{O}, \mathrm{OH}))$

\begin{tabular}{|c|c|c|c|c|c|c|c|c|}
\hline$\left.{ }^{\circ} \mathrm{C}\right)$ & $\mathrm{Na}$ & $\mathrm{Ca}$ & K & $\mathrm{Mg}$ & $\mathrm{Fe}^{+2}$ & $\mathrm{Ti}$ & Al & Si \\
\hline 72 & $0.03 \pm .01$ & $.14 \pm .05$ & $.02 \pm .01$ & $1.65 \pm .14$ & $4.87 \pm .33$ & $0.02 \pm .01$ & $3.19 \pm .12$ & $5.21 \pm .15$ \\
\hline 119 & $0.13 \pm .03$ & $.20 \pm .03$ & $2 \pm 07$ & $5 \pm .15$ & $4.93 \pm .33$ & $5 \pm .03$ & $09 \pm .21$ & $4 \pm .21$ \\
\hline 161 & $23 \pm .01$ & $20 \pm .01$ & $6 \pm$ & $0 \pm .18$ & $4.22 \pm$ & 1 & 03 & $67 \pm .11$ \\
\hline 209 & $0.11 \pm .03$ & $.20 \pm .05$ & $0.05 \pm .04$ & $1.92 \pm .06$ & $4.53 \pm .25$ & & $3.24 \pm .25$ & $.30 \pm .30$ \\
\hline & $0.22 \pm .03$ & 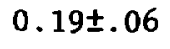 & $0.62 \pm .18$ & $1.43 \pm .06$ & 4.112 .225 & $0.05 \pm .03$ & 4 & 22 \\
\hline & $.22 \pm .03$ & $.07 \pm .04$ & $.12 \pm .04$ & $.33 \pm .17$ & $4.97 \pm .26$ & $.06 \pm .02$ & $2.92 \pm .11$ & $5 \pm \pm .20$ \\
\hline
\end{tabular}

alteration. Original nontronite and matrix rapidly recrystaliized both at the surface and in the interior of the rock. Nontronite reacts at all temperatures with solution to form smectite similar in composition to that shown in Table $V$. Matrix, although rare at higher temperatures $\left(270\right.$ and $\left.310^{\circ} \mathrm{C}\right)$, becones increasingly anorthitic and is almost completely devoid of free silica even at $72^{\circ} \mathrm{C}$.

At temperatures of 72 to $209^{\circ} \mathrm{C}$, the entire surface is covered by an aluminum silicate of calcium and magnesium with very variable iron content. SEM examinations suggest the material. is a smectite with some enclosec! mgnetite. 
MATRIX NORM An (\%)

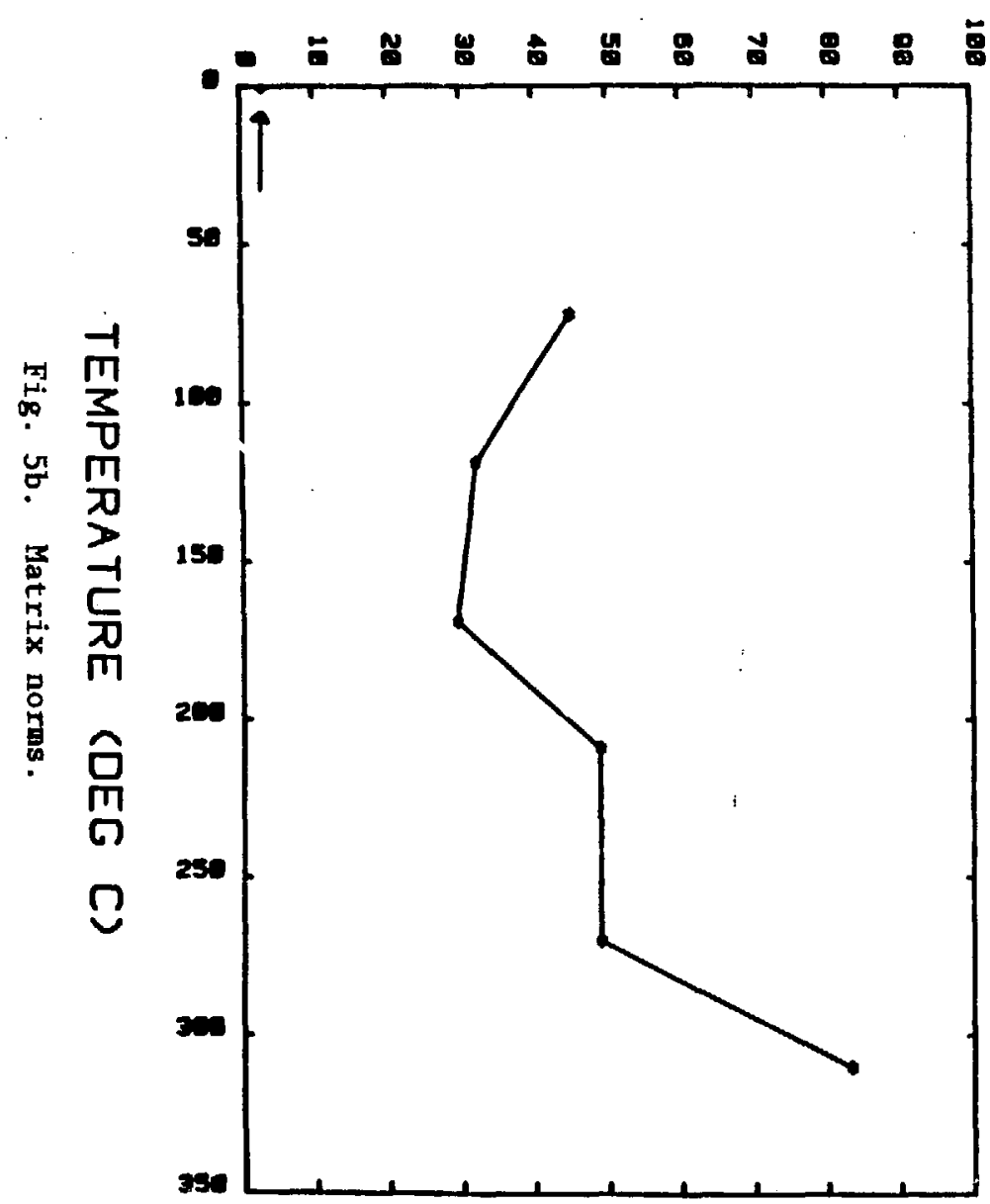

MATRIX NORM O (\%)

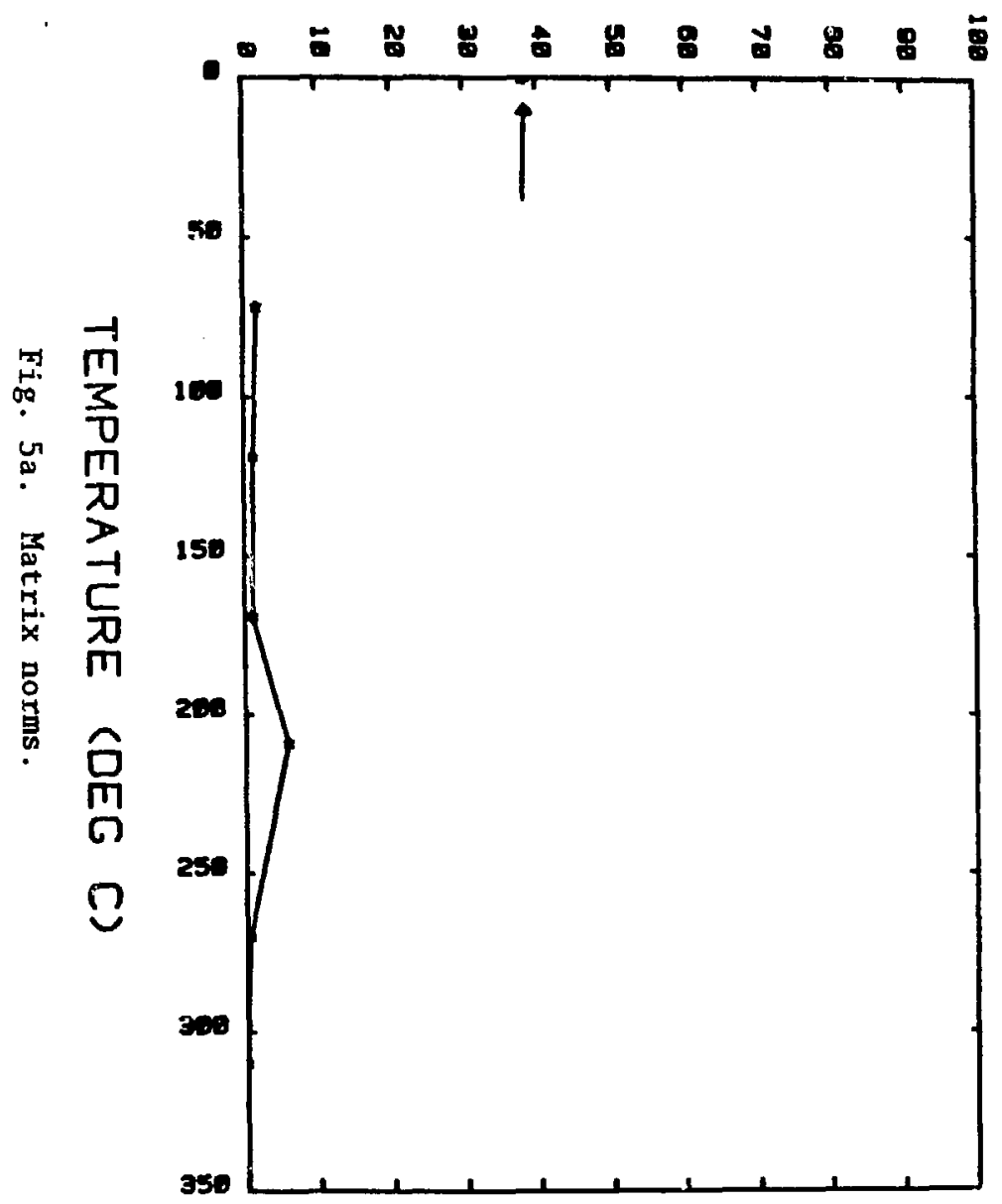




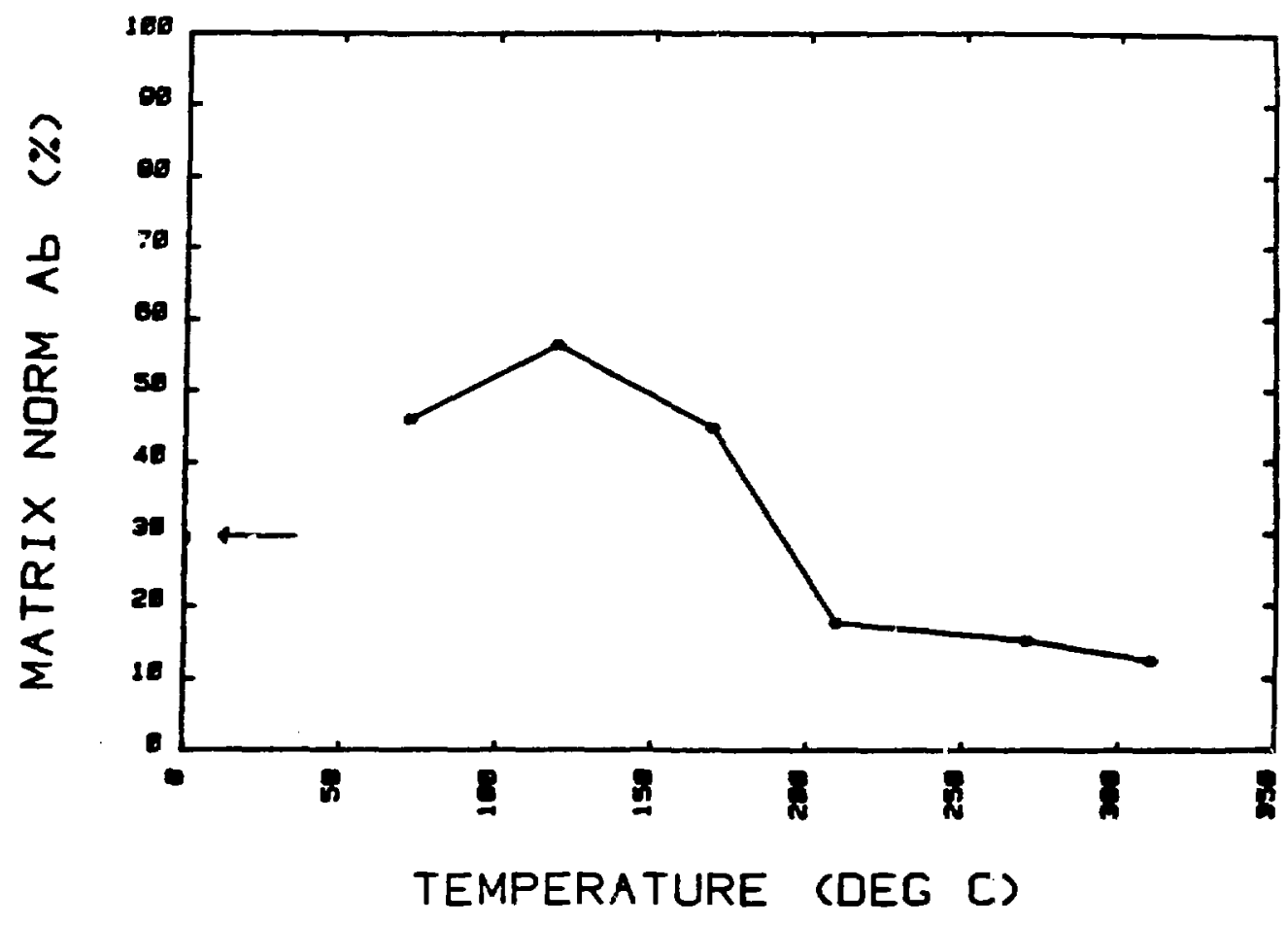

Fig. 5c. Matrix norms.

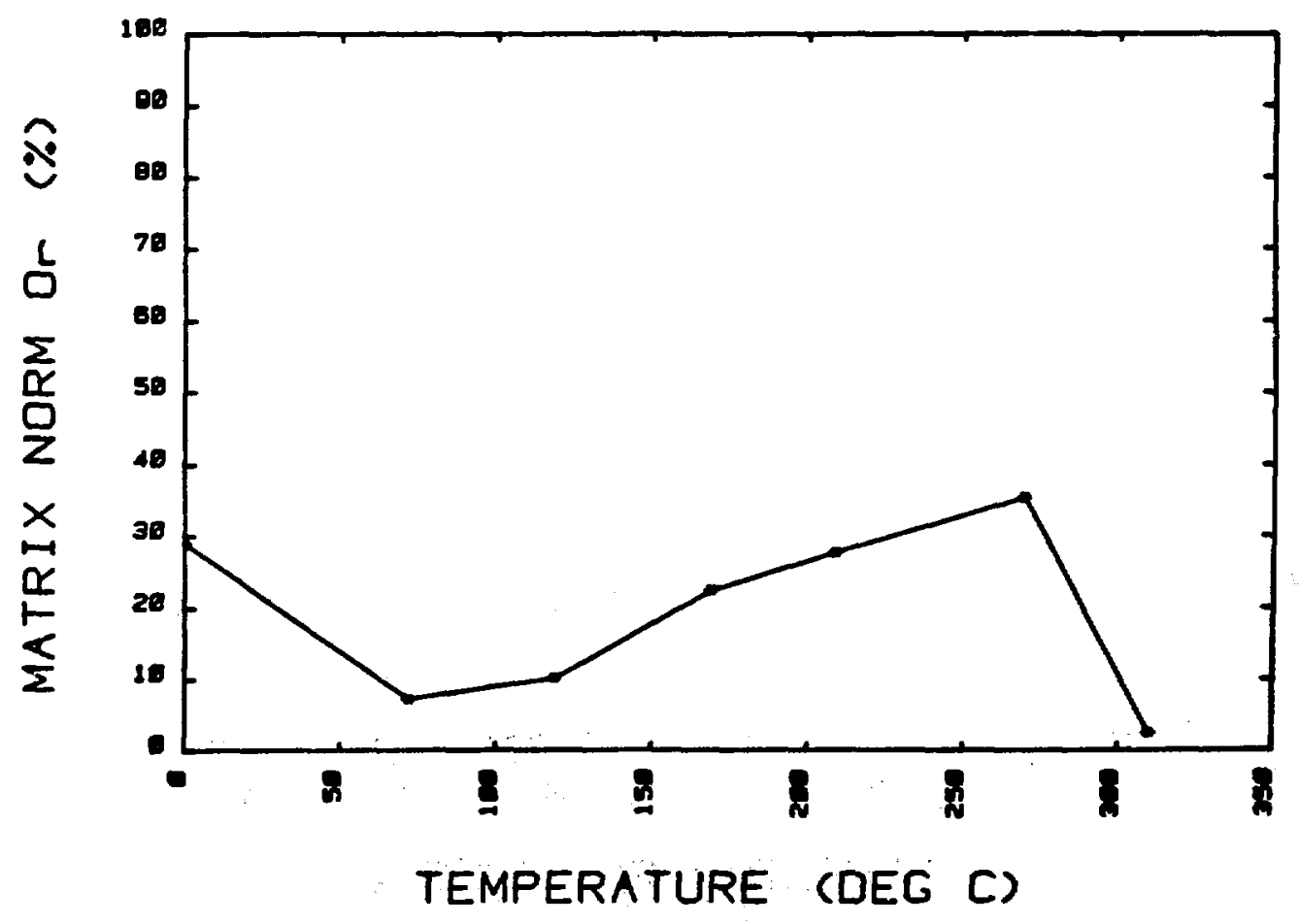

Fig. 5d. Matrix norms. 


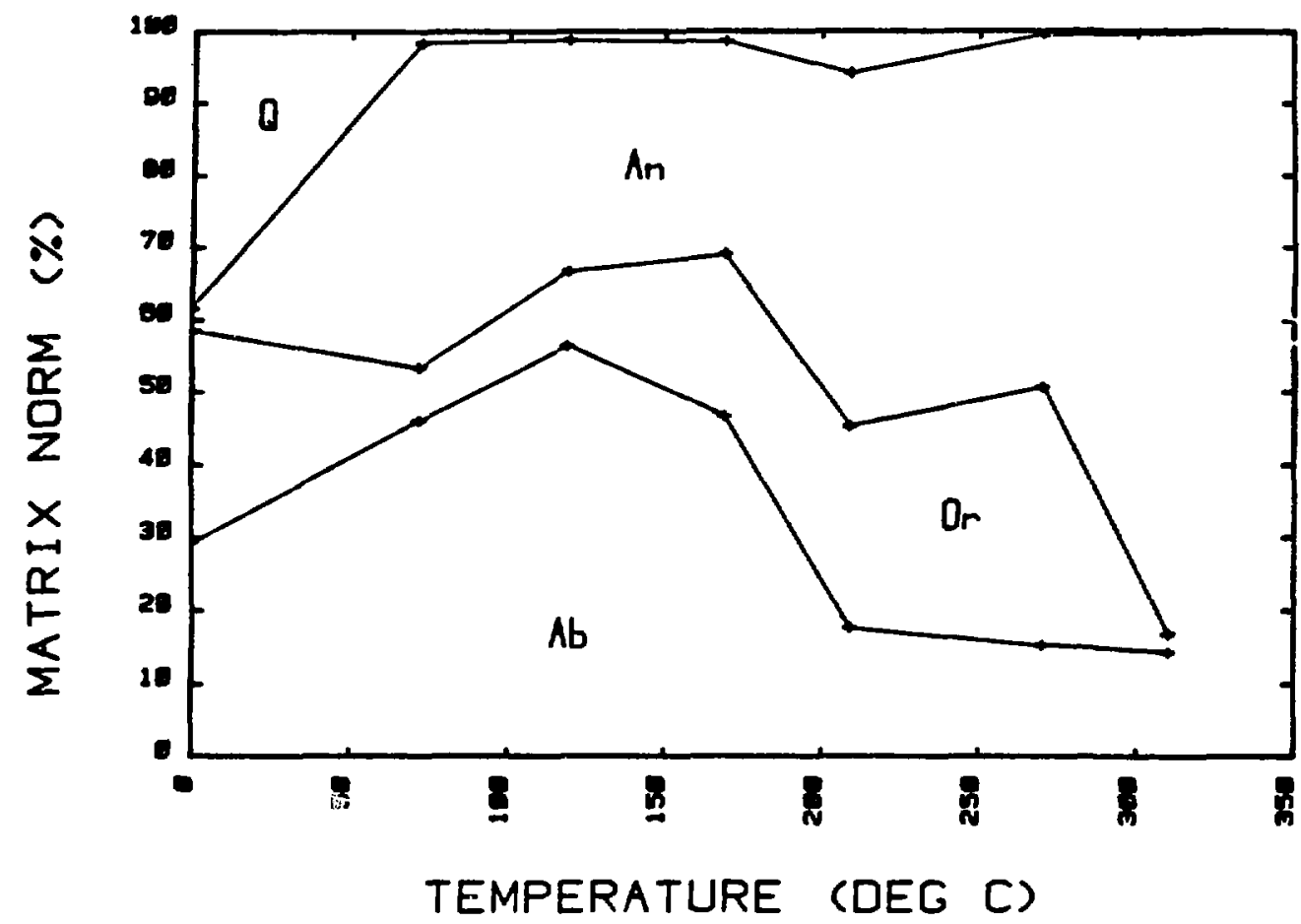

Fig. 5e. Matrix norms.

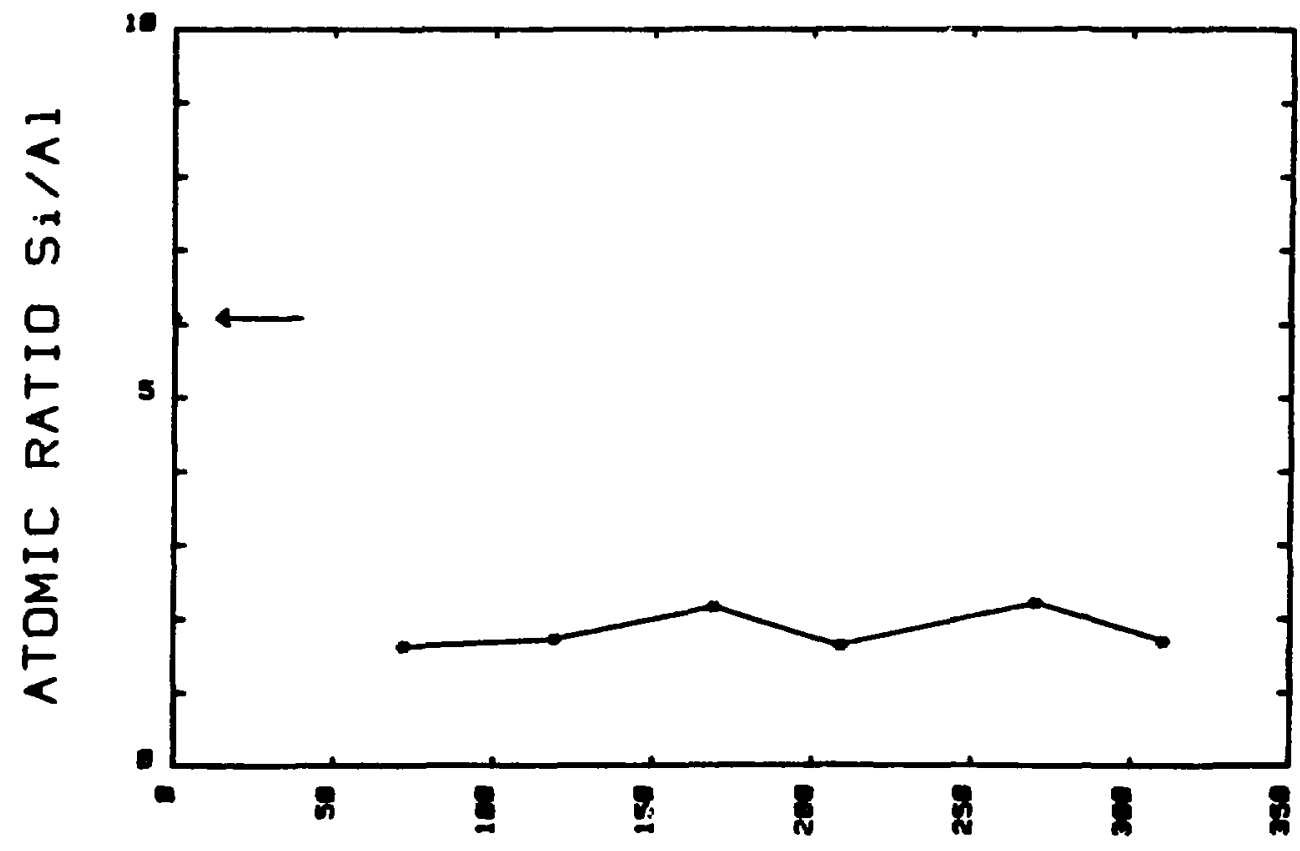

TEMPERATURE (DEG C)

Fig. 6. Si/Al for original nontronite and reacted nontronite. 
TABLE V

SURFACE ANALYSES

\begin{tabular}{c}
$\mathrm{T}$ \\
\hline$\left.{ }^{\circ} \mathrm{C}\right)$ \\
\hline 119
\end{tabular}

$72,119,161$, 209

270,310
Phase

Clay approx. $\mathrm{Ca}_{0.5} \mathrm{Mg}_{2} \mathrm{Fe}_{3.5} \mathrm{AlSi}_{5} \mathrm{Al}_{3} \mathrm{O}_{20}(\mathrm{OH})_{4}$ "Smectite"
Clay approx. $\mathrm{KMg}_{3} \mathrm{Fe}_{3.5} \mathrm{Al}_{2} \mathrm{Si}_{6} \mathrm{O}_{20}(\mathrm{OH})_{4}$ "Phengite"

Feldspar approx. $\mathrm{Na}_{0.5} \mathrm{~K}_{0.5} \mathrm{AlS}_{3} \mathrm{O}_{8}$

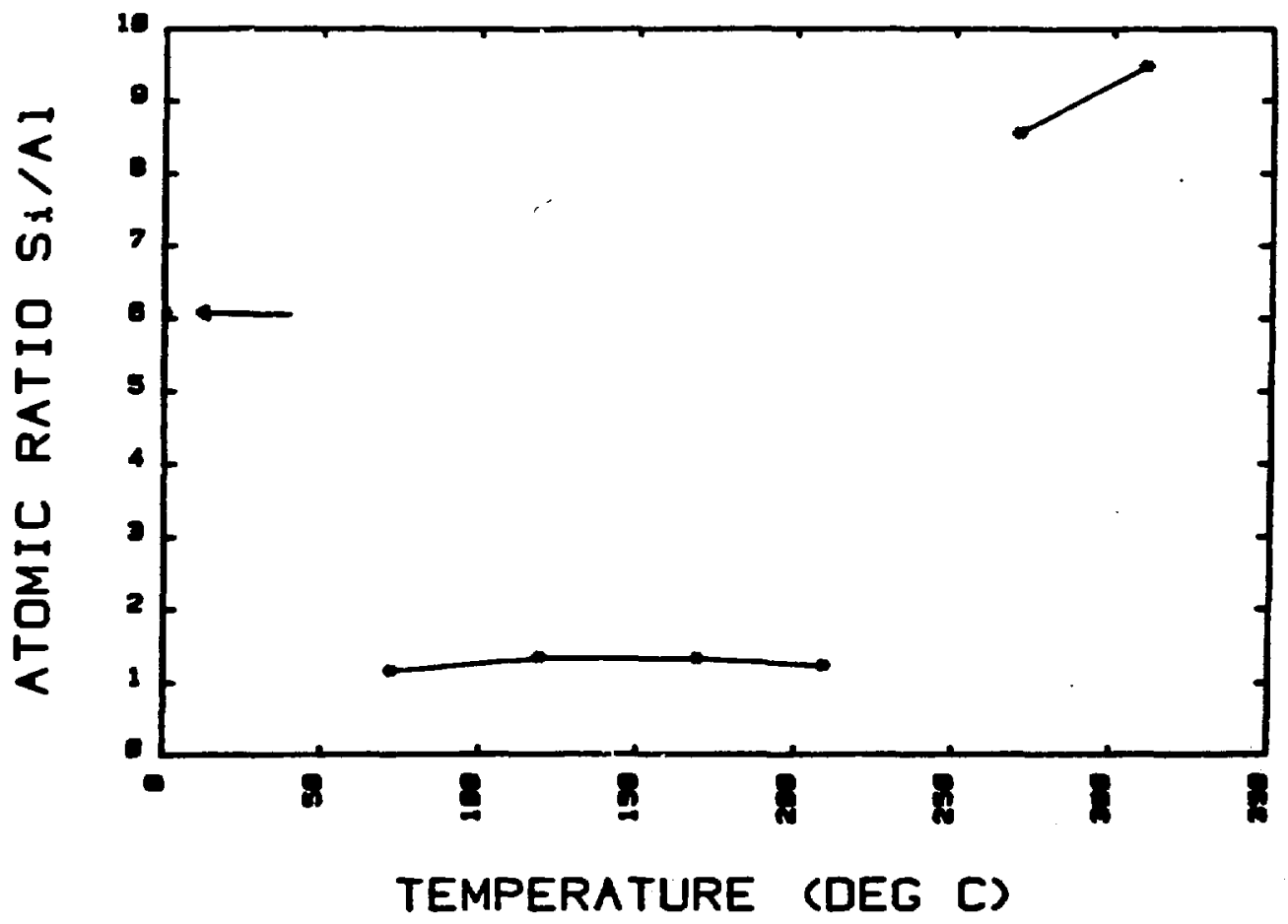

Fig. 7. Si/Al for surface alterations. 
At $270^{\circ} \mathrm{C}$ and $310^{\circ} \mathrm{C}$, phengite (potassium-rich) clay plus magnetite and sanidine covers principally original plagioclase and pyroxene.

The clays are reasonable phases for the physical conditions of the experiment. Adularia, analcime, and silica presumably would be the stable phases instead of sanidine. Exsolution under these conditions would be quite sluggish. The anorthite matrix will eventually recrystallize to a calcium-zeolite.

Amorphous silica scale and a small amount of sanidine indicate depletion of silica and to some extent potassium and sodium from the original rock matrix. B. Chemical Geothermometry

The $\mathrm{Na}-\mathrm{K}-\mathrm{Ca}$, Na-K, and silica geothermoneters were empirically developed from hydrothermal systems equilibrated with granitoid rock. Employing these techniques to basaltic systems is hazardous. In the present experiment because of the micropegmatite, we felt the $\mathrm{Na}-\mathrm{K}-\mathrm{Ca}$ geothermometer may have some application. As Table VI shows, this chemical geothermoneter yields high temperatures. The silica chemical geothermometer will yield temperatures that are too low. More experimentation must be done to develop a suitable chemical geothermometer for basaltic rock.

\section{Phase Relations}

This section will attempt to define, in more detail, some of the phase relations occurring on the prisms. The original minerals and secondary minerals are approximated in Table VII. Because of the small amount of pigeonite, pyroxene is simplified as augite.

TABIE VI

CHEMICAL GEOTHERMOMETER TEMPERATURES BASED UPON THE Na-K-Ca GEOTHERMOMETER

\begin{tabular}{ccc}
$\begin{array}{c}\text { Duration } \\
\text { (days) }\end{array}$ & $\begin{array}{c}\text { Coid Solution } \\
\left({ }^{\circ} \mathrm{C}\right)\end{array}$ & $\begin{array}{c}\text { Hot Solution } \\
\left({ }^{\circ} \mathrm{C}\right)\end{array}$ \\
\cline { 1 - 3 } 1 & 345 & -- \\
2 & 369 & 364 \\
6 & 368 & 375 \\
14 & 349 & 367 \\
30 & 326 & 340
\end{tabular}


TABLE VII

COMPOSITIONAL APPROXIMATION USED IN THE SCHREINEMAKER

DEVELOPMENT BASED ON MICROPRDBE AND SEM AKALYSES

Phase

auigite (A)

plagioclase (P)

nontronite (N)

magnetite $(M)$

phengite (F)

(illite)

smectite (S)

Composition

$$
\begin{aligned}
& \mathrm{Ca}_{0.5} \mathrm{Fe}_{0.5} \mathrm{MgSi}_{2} \mathrm{O}_{6} \\
& \mathrm{Na}_{0.5} \mathrm{Ca}_{0.5^{\mathrm{Al}}}{ }_{1.5^{\mathrm{Si}}} \mathrm{S}_{2.5} \mathrm{O}_{8} \\
& \mathrm{Ca}_{0.33^{\mathrm{Mg}}}{ }_{1.5} \mathrm{Fe}_{3.5} \mathrm{Al}_{1.33^{\mathrm{Si}}}{ }_{7.33^{\mathrm{O}_{20}}}{ }^{\mathrm{OH})_{4}} \\
& \mathrm{Fe}_{3} \mathrm{O}_{4} \\
& \mathrm{KMg}_{3} \mathrm{Fe}_{3.5} \mathrm{Al}_{2} \mathrm{Si}_{6} \mathrm{O}_{20}(\mathrm{OH})_{4} \\
& \mathrm{Ca}_{0.5} \mathrm{Mg}_{2} \mathrm{Fe}_{3.5^{\mathrm{Al}}} \mathrm{Si}_{5} \mathrm{O}_{20}(\mathrm{OH})_{4}
\end{aligned}
$$

In this experiment, a rock displaying at least two mineral assemblages out of thermodynamic equilibrium reacts with a fluid initially out of equilibrium with both assemblages. Both rock and fluid change in bulk composition as the experiment proceeds. After about two weeks, a steady state is reached and continues for the duration of the experiment. At this point, there is a transient equilibrium reflected by relatively constant fluid composition causing precipitation of secondary phases uniform in composition (with the exception of iron, which is thought to be due to magnetite crystals included in secondary clay) within a given prism, and from prism to prism with respect to major element content. These reactions are not reversible, but the secondary phases are reasonable for the intensive parameters of the experiment. These reactions may be treated as infiltration metasomatism after the method of Korzhinskii. 7

The minerals are part of the system $\mathrm{K}_{2} \mathrm{O}-\mathrm{Na}_{2} \mathrm{O}-\mathrm{CaO}-\mathrm{HgO}_{\mathrm{O}}-\mathrm{FeO}-\mathrm{Fe}_{2} \mathrm{O}_{3}-\mathrm{Al}_{2} \mathrm{O}_{3}-\mathrm{SiO}_{2}-$ $\mathrm{H}_{2} \mathrm{O} . \mathrm{K}_{2} \mathrm{O}, \mathrm{Na}_{2} \mathrm{O}, \mathrm{O}_{2}, \mathrm{SiO}_{2}, \mathrm{Al}_{2} \mathrm{O}_{3}$, and $\mathrm{H}_{2} \mathrm{O}$ are mobile components, whereas CaO, $\mathrm{MgO}$, and $\mathrm{FeO}$ are the inert components. Mobile and inert components may be chosen in any reasonable manner. Because of the relatively low solution concentration of calcium, magnesium, and iron, these elements are chosen as inert. Additional elements will result in a more complex chemographic net but will still contain this subnet. Mobile phases are quartz, water, sanidine (actually adularia plus albite) oxygen, and complexes containing $\mathrm{K}^{+}, \mathrm{Na}^{+}$, and $\mathrm{Al}^{+}$. The entire chemographic systex consists of three components and six phases (Table VII) and, thus, has one negative degree of freedom. No conpositional degeneracies exist for this systea. A11 6 invariant assemblages, 15 univariant assemblages, and 20 divariant assemblages exist. 
A connected net for this system is shown in Fig. 8. All divariant fields are labeled. Important divariant assemblages are smectite bearing, phengite bearing, and non-hydrous phase bearing (high temperature). Some observations limit the pertinent assemblages with respect to this experiment.

(1) Magnetite appears to be present with smectite and phengite.

(2) Smectite and phengite do not appear together.

(3) Nontronite never appears in the reacted rock.

(4) Augite is metastable at low temperature.

These observations lead to a low-temperature assemblage of magnetie, plagioclase, and smectite; a moderate-temperature assemblage of magnetite, olagioclase, and phengite; and a high-temperature assemblage of magnetite, plagioclase, and augite.

The two possible nets oriented in $\mu_{\mathrm{H} 2 \mathrm{O}}-\mu_{\mathrm{SiO2}}$ space are shown in Figs. 9 and 10. Only the important phase assemblages are labeled in these figures. One possible reaction path is labeled. This is the only region on the two diagrams that presents the proper sequence of reaction from nore to less hydrous phases with relatively constant silica content.

\section{CONCLUSIONS}

Sentinel Gap basalt reacts readily at low temperature with water to produce an assemblage including clay minerals throughout the range of experimentation. These minerals may be useful as adsorbers for material emplanted in the basalt. Sorption capabilities should be investigated with specific ions in mind. 


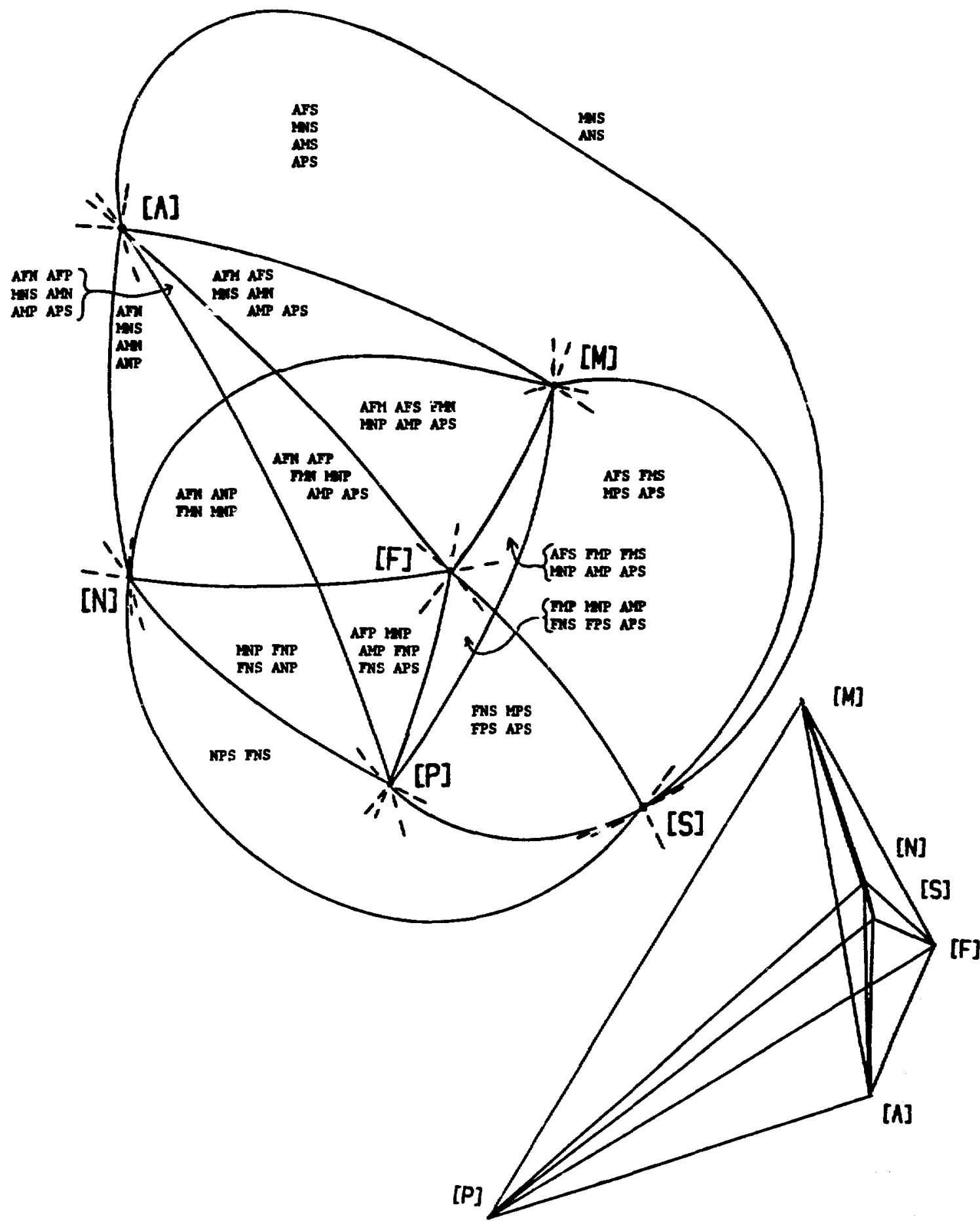

Fig. 8. Connected net and comositional polyhedron. 


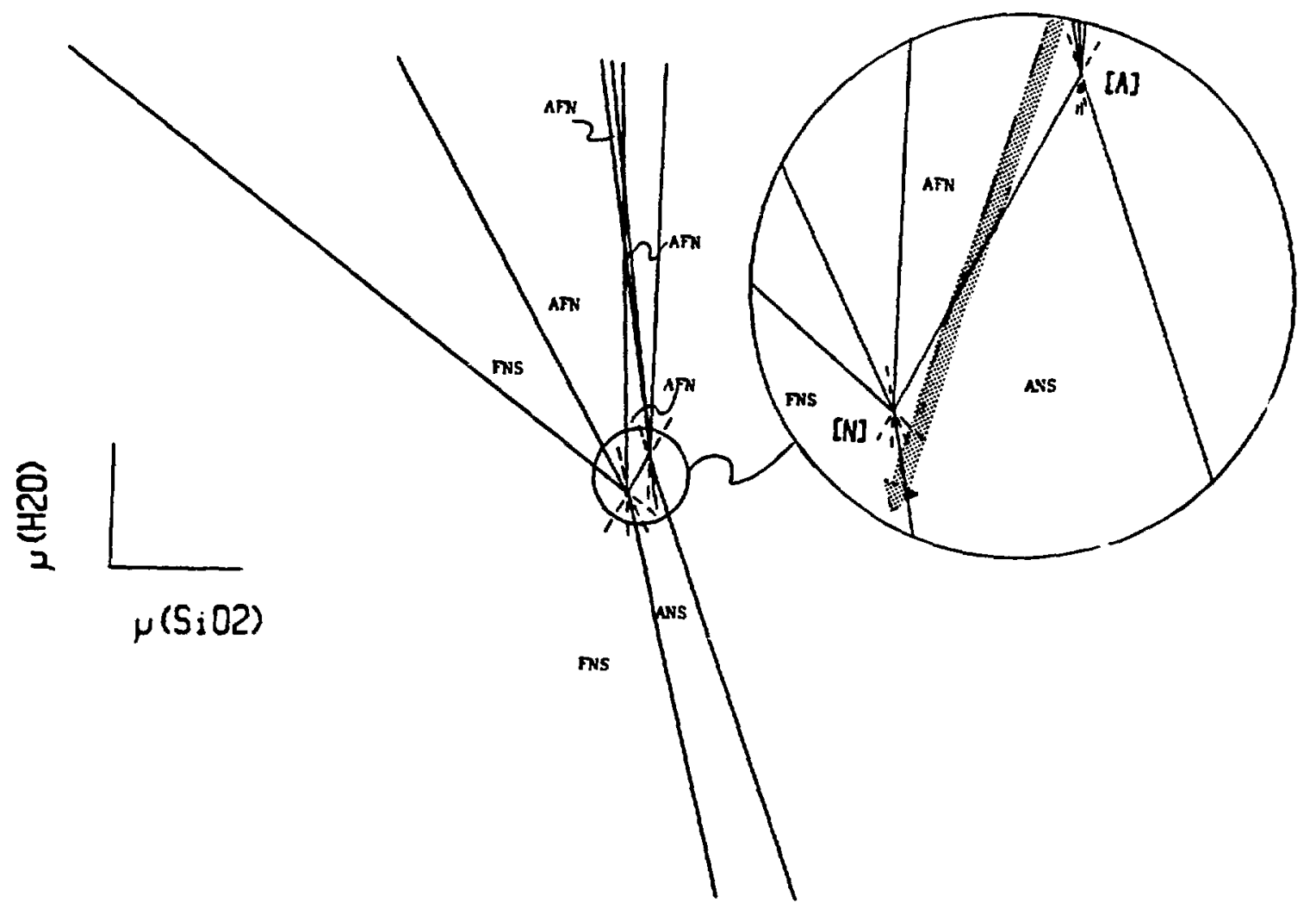

Fig. 9. Net oriented in $\mu_{\mathrm{H}_{2} \mathrm{O}}-\mu_{\mathrm{SiO}}$ space with [S] to [F] homotypical metastable. 


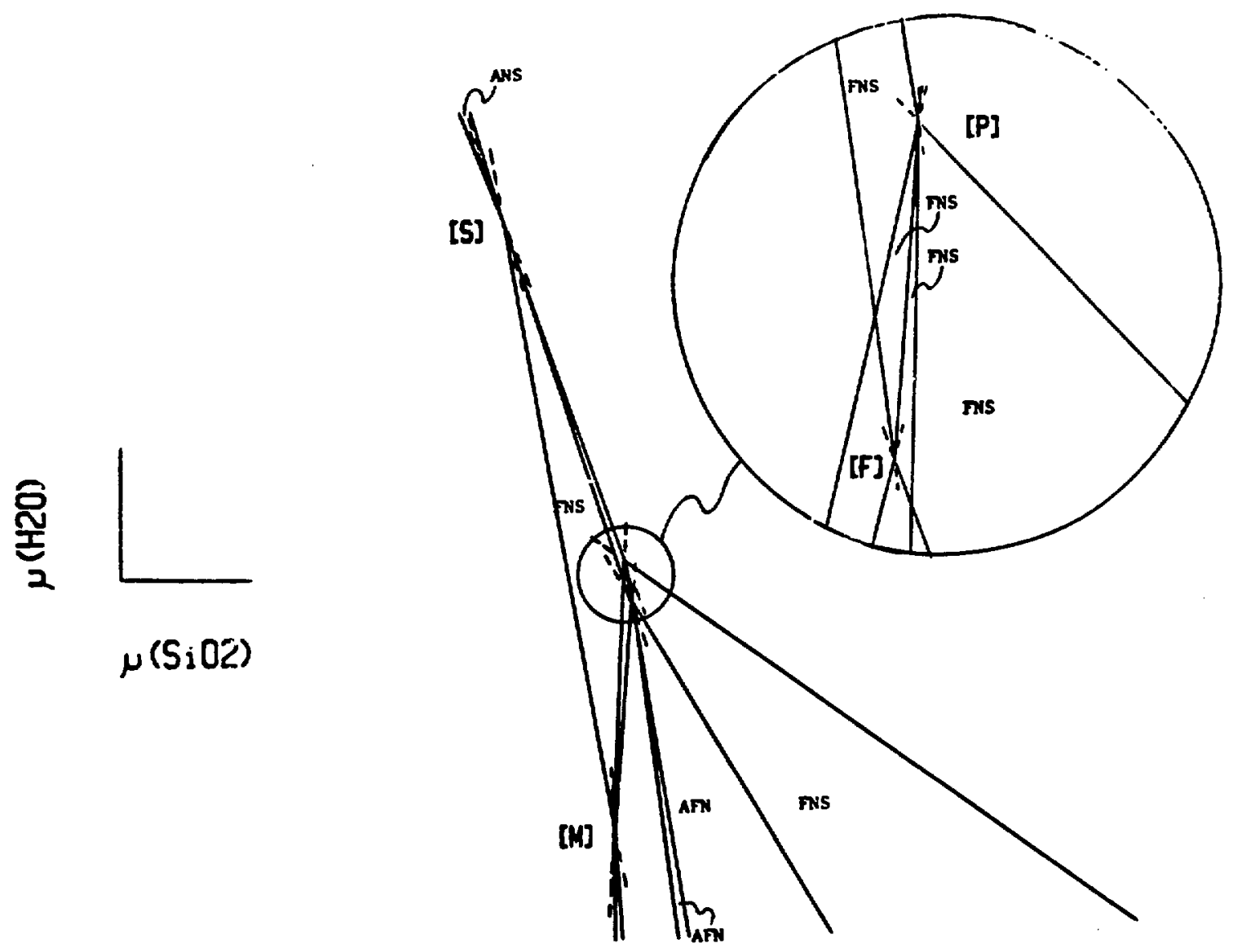

Fig. 10. Net oriented in $\mu_{\mathrm{H}_{2} \mathrm{O}}-\mathrm{H}_{\mathrm{SiO}_{2}}$ space with [S] to [F] homotypical stable. 


\section{REFERENCES}

1. M. J. Smith, Ed., "Engineered Barrier Development for a Nuclear Waste Repository in Basalt: An Integration of Current Knowledge," Rockwe11 Hanford Operations informal report RHO-BWI-ST-7 (1980).

2. C. L. Taylor, G. J. Anttonen, J. E. O'Rourke, M. R. Niccun, "Borehole Plugging of Man-Made Accesses to a Basalt Repository: A Prelininary Study," Rockwell Hanford Operations informal report RHO-BWI-C-49 (1979).

3. C. L. Taylor, J. E. O'Rourke, D. Allivat, and $Y$ O'Conner, "Preconceptual Systems and Equipment for Plugging of Yan-Made Accesses to a Repository in Basa1t," Rockwell Hanford Operations informal report RHO-BWI-C-67 (1980).

4. W. E. Coons, E. L. Moore, M. J. Smith and J. D. Kaser, "The Functions of an Engineered Barrier System for a Nuclear Waste Repository in Basalt," Rockwe11 Hanford Operations informal report RHO-BW1-LD-23 (1980).

5. R. W. Charles and G. K. Bayhurst, "Rock Fluid Interactions in a Temperature Gradient: Biotite Granodiorite $+\mathrm{H}_{2} \mathrm{O}$," J. Volcanol. Geotherm. Res., to be published.

6. R. W. Charles, G. K. Bayhurst, and R. J. Vidale, "Two Dynamic Hydrothermal Systems and Fluid Samplers for Studying Rock-Fluid Interactions," Los Alamos Scientific Laboratcry report LA-7766-MS (April 1979).

7. D. S. Kurzhinskii, Theory of Metasomatic ?oning (Clarendon Press, Oxford, 1970), p. 162 .

APPENDIX
PHOTOMOSAICS OF BASALT

The following figures are scanning electron photomosaics of basalt prisus in various stages of the reaction process. 


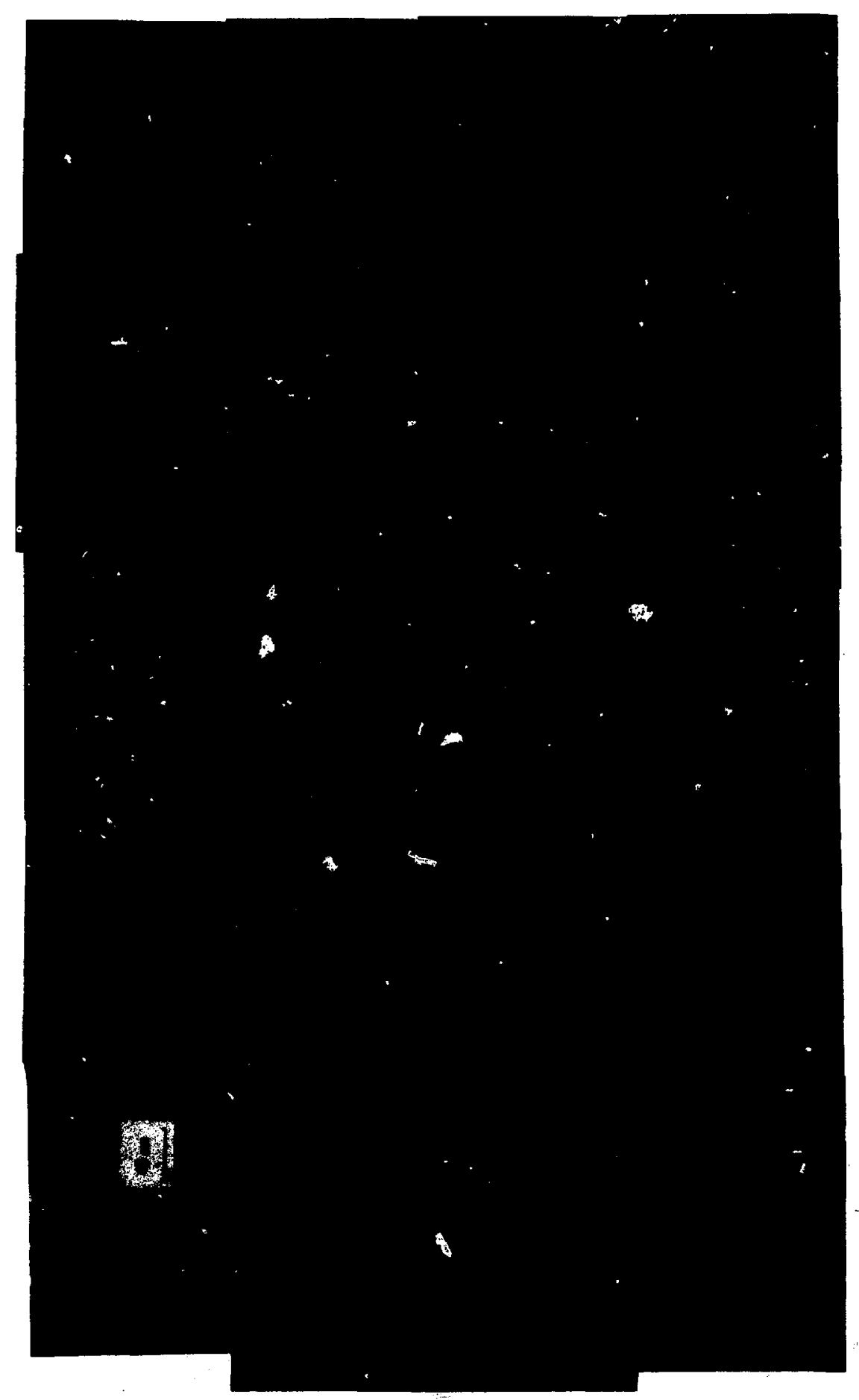

Fig. A-1. SEM photomosaic of a portion of a polished unreacted basalt prisa. 


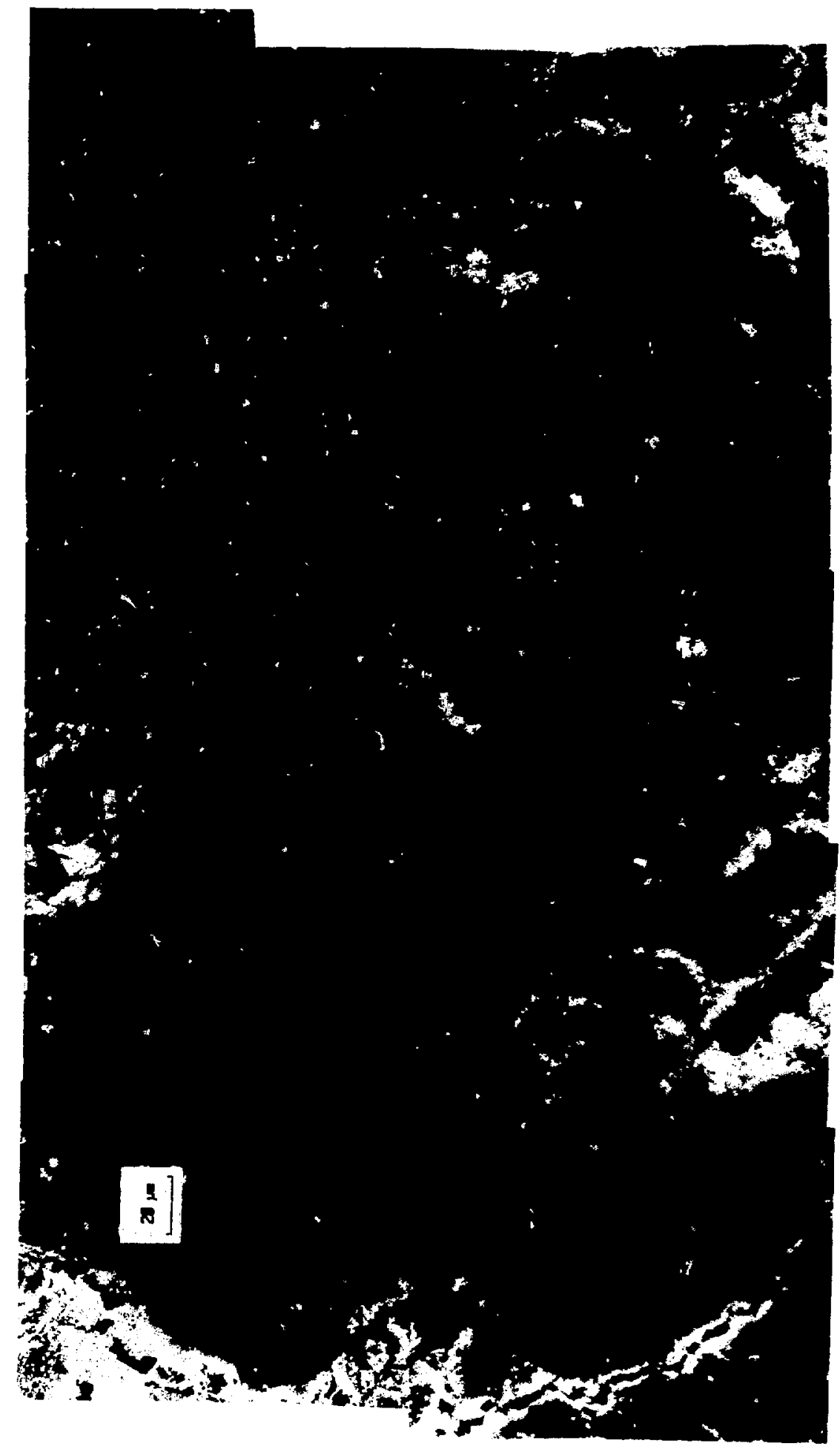

Fig. A-2. SEM photomosaic of a portion of a prisn reacted at $72^{\circ} \mathrm{C}$. 


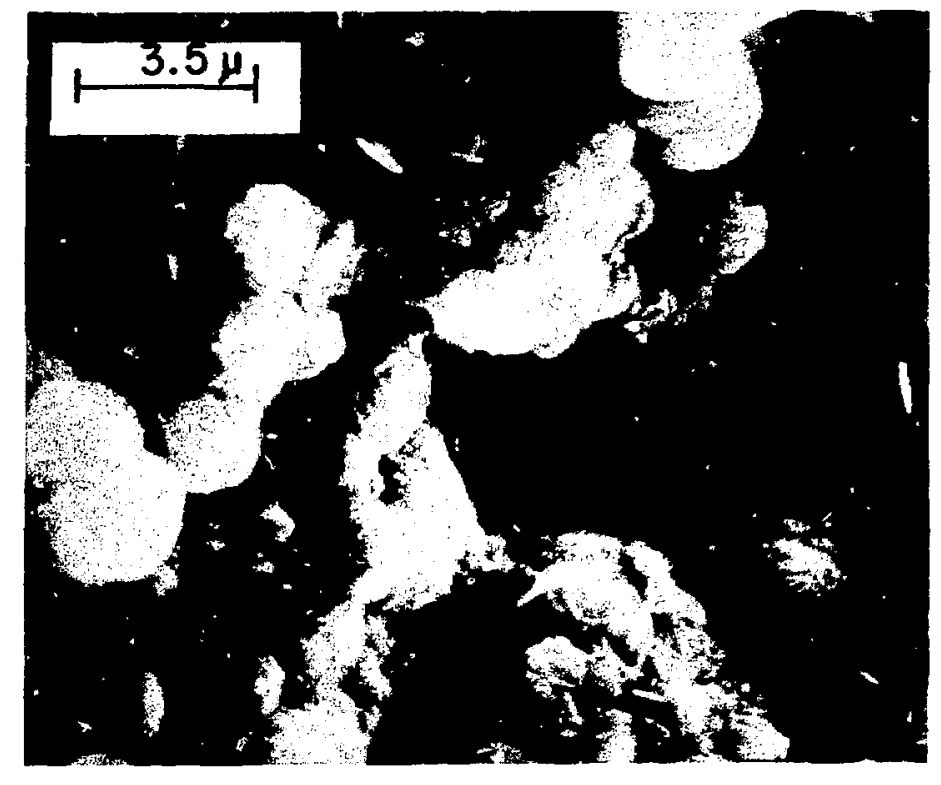

$72^{\circ} \mathrm{C}$

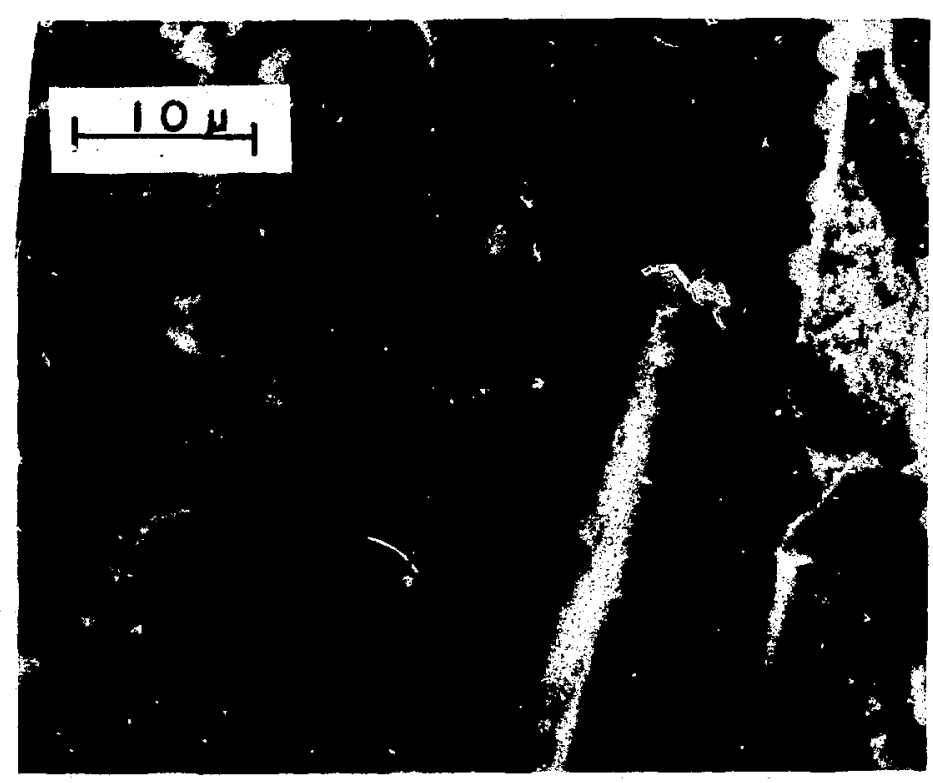

$72^{\circ} \mathrm{C}$

Fig. A-3. Secondary plasey material grown at $72^{\circ} \mathrm{C}$. 


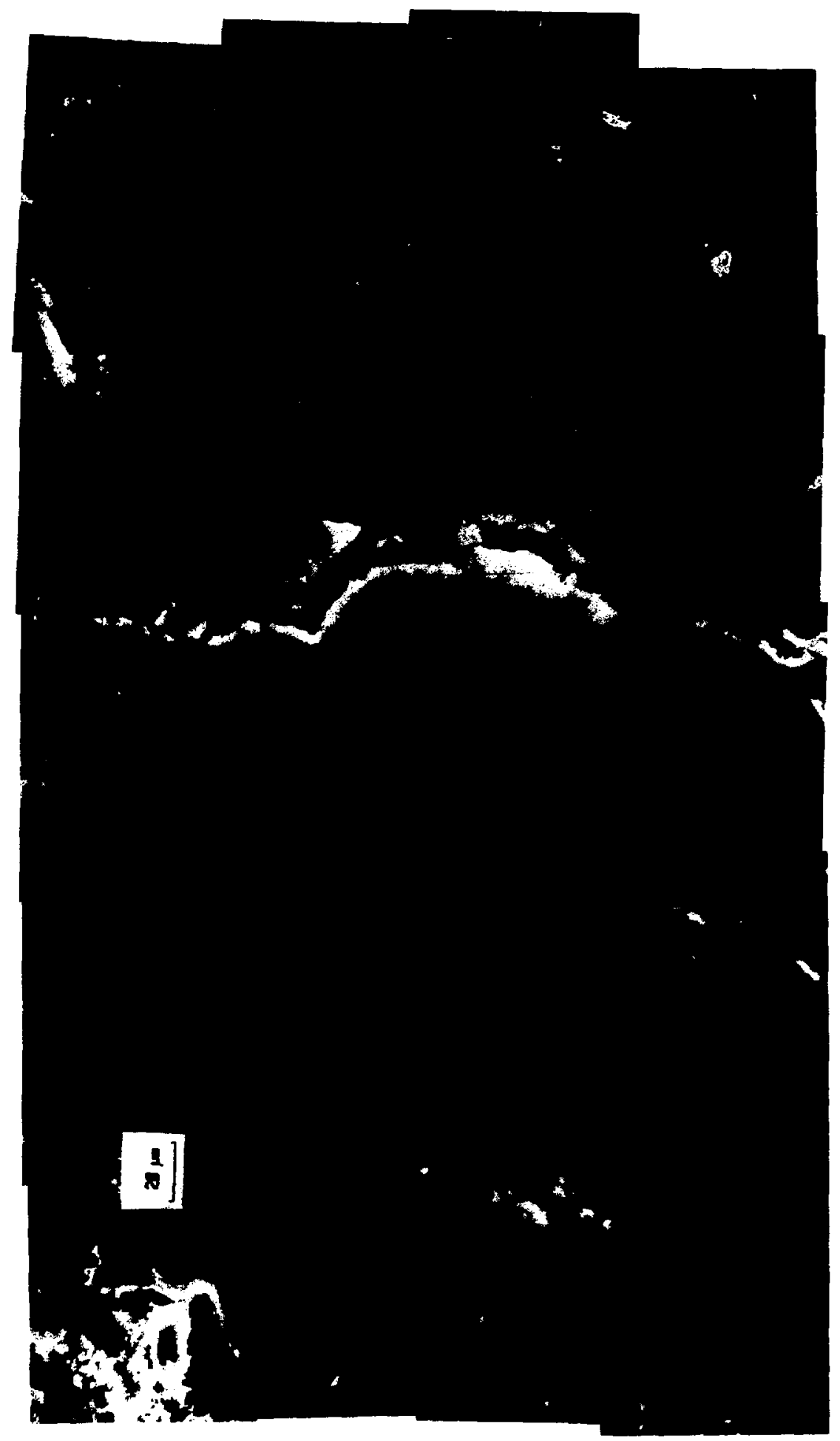

Fig. A-4. Higher magnification of the platey aggregates showing more complete coverage of the rock surface reacted at $119^{\circ} \mathrm{C}$. 


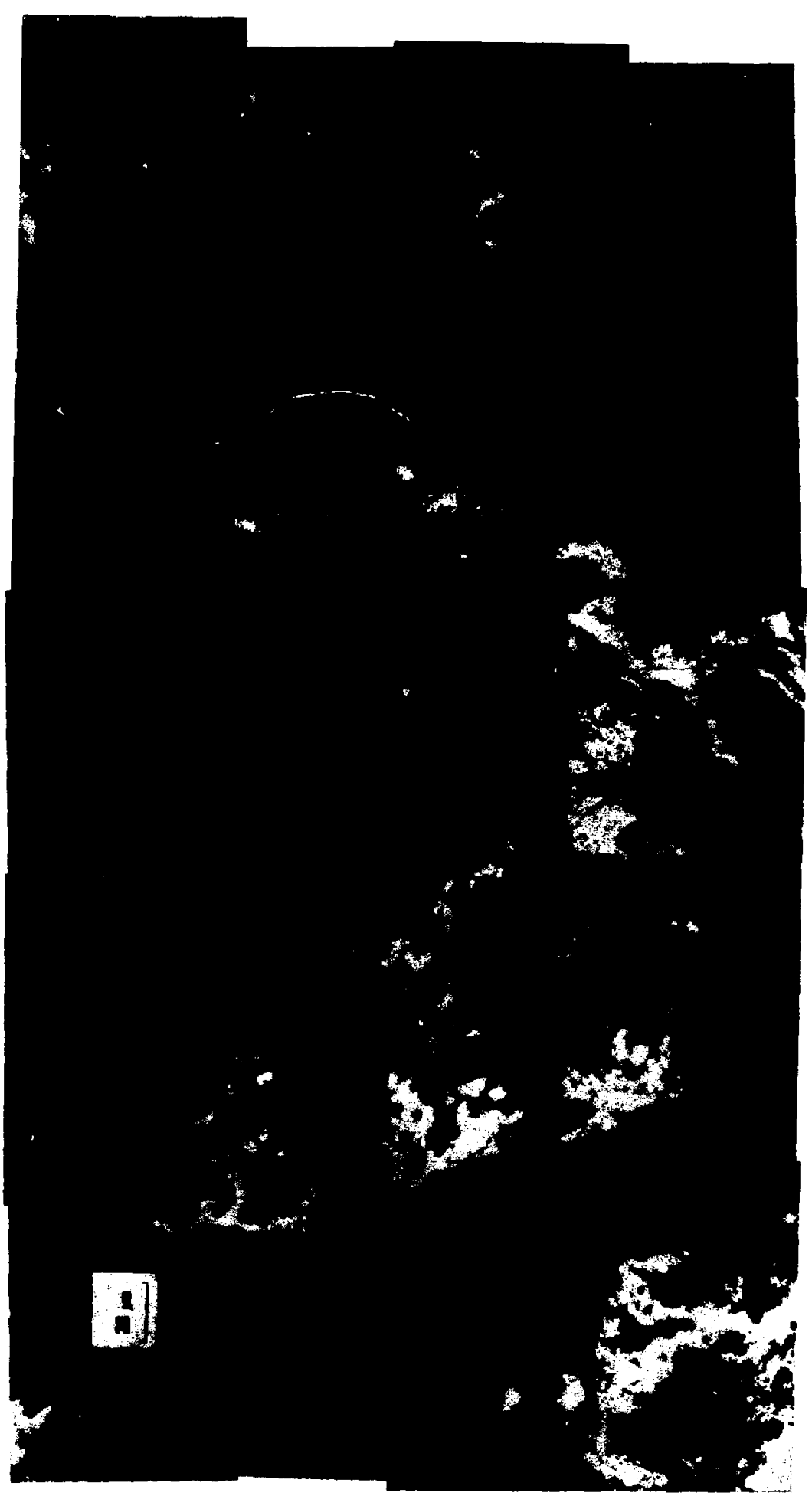

Fig. A-5. SEM photomosaic of a portion of a prism reacted at $161^{\circ} \mathrm{C}$. 


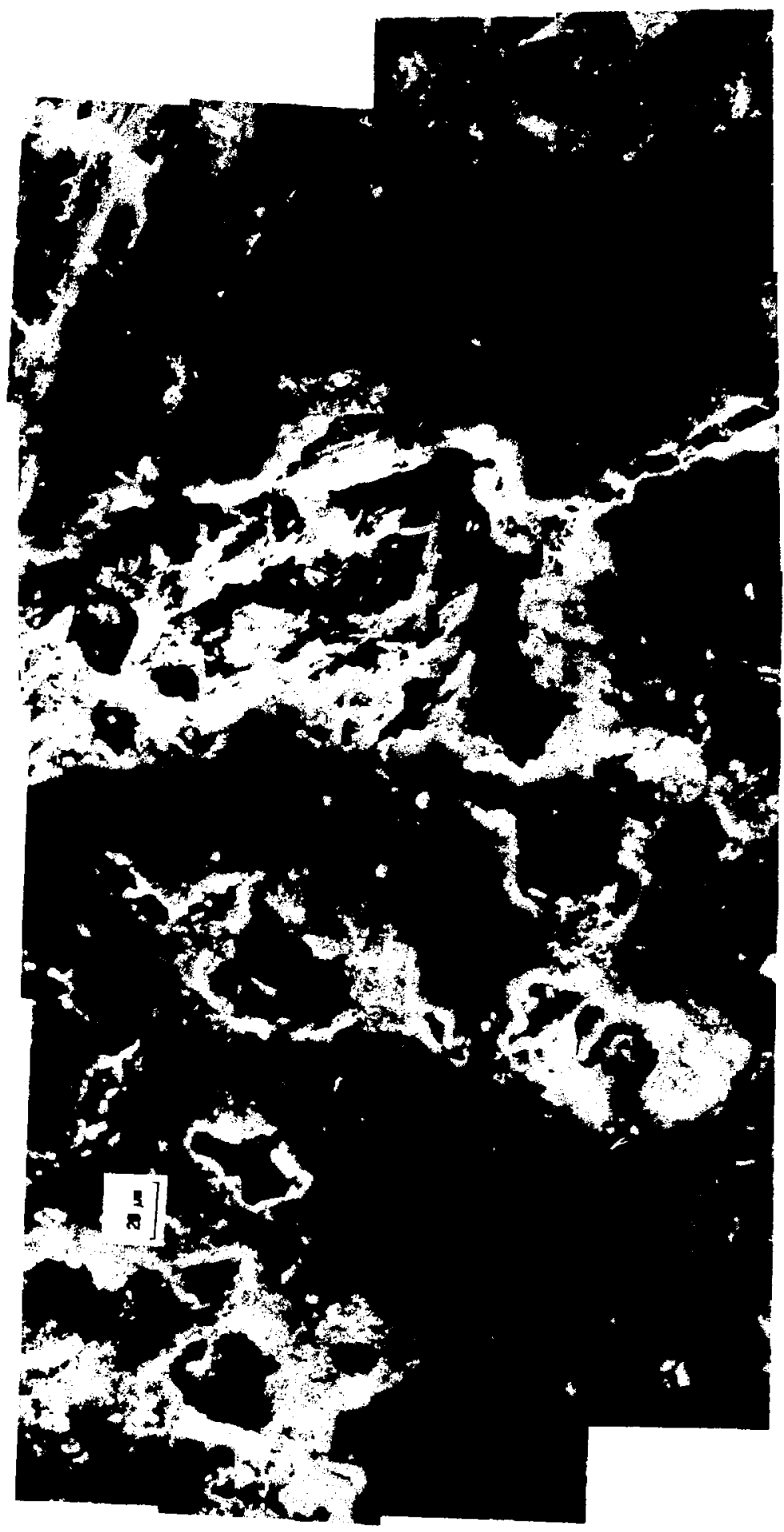

Fig. A-6. SEM photomosaic of a portion of a prism reacted at $209^{\circ} \mathrm{C}$. 


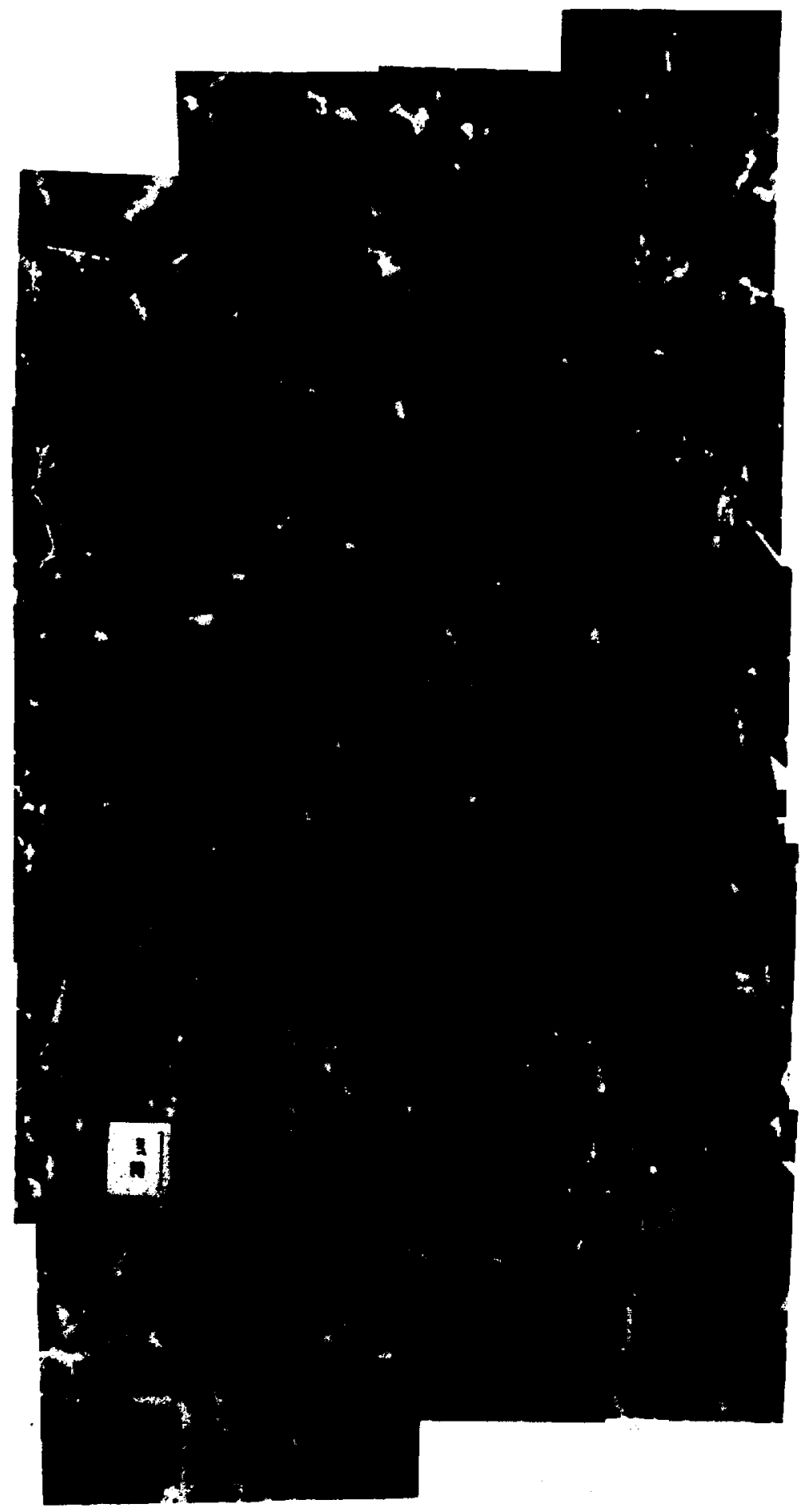

Fig. A-7. SEM photomosaic of a portion of a prism reacted at $270^{\circ} \mathrm{C}$ showing strinkingly different overgrowth morphology. 


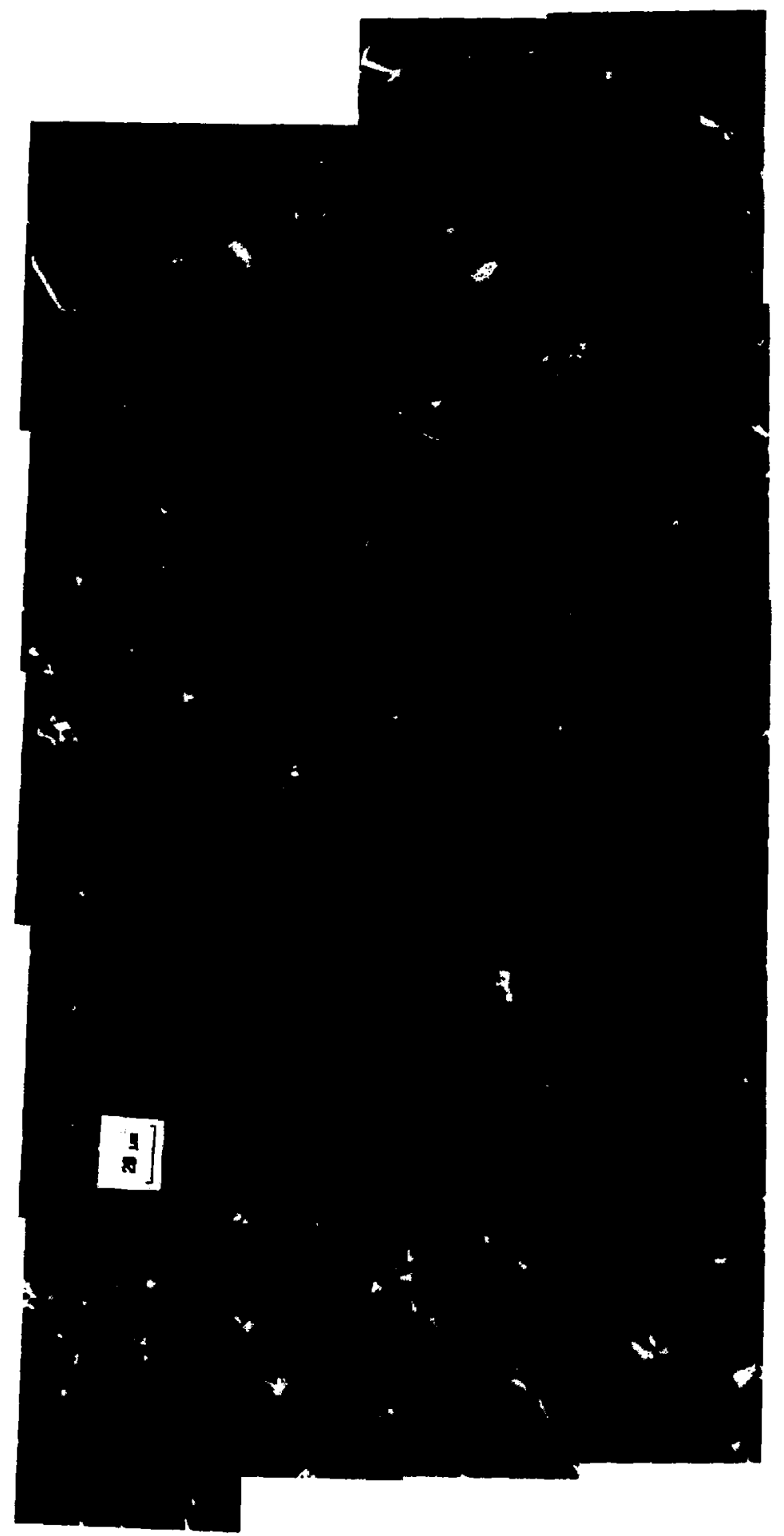

Fig. A-8. SEM photomosaic of a portion of a prism reacted at $310^{\circ} \mathrm{C}$ showing slightly better crystallization of the feldspars. 